GLOBAL WATER PATHOGEN PROJECT

PART THREE. SPECIFIC EXCRETED PATHOGENS: ENVIRONMENTAL AND EPIDEMIOLOGY ASPECTS

\title{
GIARDIA DUODENALIS
}

\section{Érica Boarato-David}

São Paulo State University

São Paulo, Brazil

Semiramis Guimarães

São Paulo State University

São Paulo, Brazil

Simone Cacciò

Istituto Superiore di Sanità

Rome, Italy 


\section{Copyright:}

\section{cc) (i) (2) \\ BY SA}

This publication is available in Open Access under the Attribution-ShareAlike 3.0 IGO (CC-BY-SA 3.0 IGO) license (http://creativecommons.org/licenses/by-sa/3.0/igo). By using the content of this publication, the users accept to be bound by the terms of use of the UNESCO Open Access Repository (http://www.unesco.org/openaccess/terms-use-ccbysa-en).

\section{Disclaimer:}

The designations employed and the presentation of material throughout this publication do not imply the expression of any opinion whatsoever on the part of UNESCO concerning the legal status of any country, territory, city or area or of its authorities, or concerning the delimitation of its frontiers or boundaries. The ideas and opinions expressed in this publication are those of the authors; they are not necessarily those of UNESCO and do not commit the Organization.

\section{Citation:}

Boarato-David, E., Guimarães, S., and Cacciò, S. (2017). Giardia duodenalis. In: J.B. Rose and B. Jiménez-Cisneros (eds), Water and Sanitation for the 21st Century: Health and Microbiological Aspects of Excreta and Wastewater Management (Global Water Pathogen Project). (R. Fayer and W. Jakubowski (eds), Part 3: Specific Excreted Pathogens: Environmental and Epidemiology Aspects - Section 3: Protists), Michigan State University, E. Lansing, MI, UNESCO https://doi.org/10.14321/waterpathogens.35

Acknowledgements: K.R.L. Young, Project Design editor;Website Design: Agroknow (http://www.agroknow.com)

Last published: February 17, 2017 


\section{Summary}

Giardia duodenalis (synonyms, G. lamblia and $G$. intestinalis) is a flagellated protozoan and the etiological agent of giardiasis, a very common gastrointestinal disease of humans and animals. The simple life cycle of this parasite comprises a vegetative stage, the trophozoite, and a transmittable stage, the cyst. Transmission occurs directly, by contact between hosts, and indirectly, through ingestion of contaminated water and food.

Humans are infected by two of the eight currently recognized genotypes of $G$. duodenalis, namely assemblages $A$ and $B$, which are likely to represent different species. Of the many factors influencing the epidemiology of giardiasis, three are of utmost importance. First, very large numbers of cysts are shed in the environment with the feces of infected hosts. Second, the infectious dose is low, theoretically, a single cyst may cause infection, and cysts are immediately infectious upon excretion. Third, cysts are remarkably resistant to environmental stress and can persist for months while retaining their infectivity. Consequently, there is a large potential for environmental contamination with Giardia cysts. This has been confirmed by surveys of water from all over the world, which have included samples from wastewater, surface water, drinking water, and swimming pools. Perhaps not surprisingly, waterborne outbreaks of giardiasis have occurred in many countries, and Giardia is second only to Cryptosporidium as a cause of waterborne gastroenteritis caused by protozoan parasites.

This Chapter will first describe the essentials of Giardia biology, then will present data on the occurrence and survival of cysts in the environment and in water and wastewater, and finally focus on the different treatment processes and their efficacy in removal and/or inactivation of cysts from water.

\section{Giardia}

Giardiais an important protozoan enteric pathogen spread by excreta and sewage associated with waterborne disease worldwide.

\subsection{Epidemiology of the Disease and Pathogen(s)}

\subsection{Global Burden of Disease}

Giardiasis is a very common gastro-intestinal infection of humans; the World Health Organization has estimated that about 200 million people in Asia, Africa, and Latin America have symptomatic infections (WHO, 1996; Yason and Rivera, 2007). The parasite has a global distribution, but the prevalence of infection is higher in developing regions of the world, where Giardia is common in both children and adults (Cacciò and Sprong, 2014). In recognition of the burden of disease caused by the parasite, and to underline its link to poverty, the WHO has included giardiasis in the list of neglected diseases since 2004 (Savioli et al., 2006).

Infection rates have been reported in both developing countries (range 8-30\%) and industrialized countries (range 1-8\%) (Cacciò, 2015). Rates are probably higher in individuals with diarrhea, but our current understanding is limited by the lack of reporting systems and monitoring programs in many countries, and by the high rate of asymptomatic carriage of Giardia in humans (Cacciò and Sprong, 2011). This suggests that giardiasis is strongly underdiagnosed and underreported.

\subsubsection{Symptomology}

Giardiasis infections are associated with watery diarrhea that is often described as foul-smelling. Diarrheal stools may be greasy and intermittent. Individuals may experience abdominal cramps, bloating, gas, nausea, and fatigue. These symptoms last for weeks and could be chronic and recurring. Failure to thrive can occur particularly in young children with weight loss in many.

\subsection{Taxonomic Classification of the Agent(s)}

Organisms in the genus Giardia are classified, based on morphology of the cyst and the trophozite, in the phylum Metamonada, subphylum Trichozoa, superclass Eopharyngia, class Trepomonadea, subclass Diplozoa and order Giardiida (Thompson and Monis, 2012). The taxonomy of Giardia species is still controversial and confusing, with different names being used for the same species. Historically, and under the assumption of strict host specificity (i.e., a different species for each host), as many as 51 species of Giardia have been described, including 30 from mammals (of which 2 were from humans), 14 from birds, 4 from amphibians, 2 from reptiles and one from fish. The first important taxonomic revision was introduced by Filice, who, after a critical revision of the data, proposed to consider only 3 morphologically distinct groups, namely Giardia muris, G. agilis and G. duodenalis. More recently, advances in microscopic techniques allowed for ultrastructural description of trophozoites, and the recognition of two new species from birds, Giardia ardeae (Erlandsen et al., 1990) and Giardia psittaci(Erlandsen and Bemrick, 1987). Another species, Giardia microti(Feely, 1988), that infects various rodents, was recognized as a separate species due to the unique presence of fully differentiated trophozoites in the cysts. Therefore, six species are currently recognized in the genus, of which Giardia duodenalis (also referred to as Giardia intestinalis or Giardia lamblia) has the largest host range and infects many mammals, including humans (Table 1). 
Table 1. Giardia species currently recognized as valid, their host distribution and distinctive morphological characteristics

\begin{tabular}{|c|c|c|c|}
\hline Species & Host & Distinctive morphologic features & Length / width of the trophozoite (mm) \\
\hline $\begin{array}{l}\text { Giardia } \\
\text { agilis }\end{array}$ & Amphibians & $\begin{array}{l}\text { Long and narrow trophozoites with } \\
\text { club-shaped median bodies. }\end{array}$ & $20-30 / 4-5$ \\
\hline $\begin{array}{l}\text { Giardia } \\
\text { ardeae }\end{array}$ & Birds & $\begin{array}{l}\text { Rounded trophozoites, prominent } \\
\text { notch in ventral disc and } \\
\text { rudimentary caudal flagellum. } \\
\text { Median bodies round-oval to claw- } \\
\text { shaped. }\end{array}$ & $\sim 10 / \sim 6$ \\
\hline $\begin{array}{l}\text { Giardia } \\
\text { duodenalis }\end{array}$ & $\begin{array}{l}\text { Humans, } \\
\text { domestic } \\
\text { and wild } \\
\text { mammals }\end{array}$ & $\begin{array}{l}\text { Pear-shaped trophozoites with } \\
\text { claw-shaped median bodies. }\end{array}$ & $12-15 / 6-8$ \\
\hline $\begin{array}{l}\text { Giardia } \\
\text { microti }\end{array}$ & Rodents & $\begin{array}{l}\text { Trophozoites similar to } G \text {. } \\
\text { duodenalis. Cysts contain fully } \\
\text { differentiated trophozoites. }\end{array}$ & $12-15 / 6-8$ \\
\hline $\begin{array}{l}\text { Giardia } \\
\text { muris }\end{array}$ & Rodents & $\begin{array}{l}\text { Rounded trophozoites with small, } \\
\text { round median bodies. }\end{array}$ & $9-12 / 5-7$ \\
\hline $\begin{array}{l}\text { Giardia } \\
\text { psittaci }\end{array}$ & Birds & $\begin{array}{l}\text { Pear-shaped trophozoites, with no } \\
\text { ventro-lateral flange. Claw-shaped } \\
\text { median bodies. }\end{array}$ & $\sim 14 / \sim 6$ \\
\hline
\end{tabular}

With the development of procedures for the propagation of trophozoites in axenic conditions, molecular comparison of Giardia strains from different hosts became possible. Investigation of protein (isoenzyme) polymorphism was first used to reveal large amounts of genetic variability among Giardia duodenalis strains. Importantly, clustering analysis of the isoenzyme data identified strongly supported groups of genetically related strains that, in most cases, were derived from specific hosts (Monis et al., 1999). These groups are nowadays referred to as Assemblages, to underline the fact that they share genetic similarities but are not identical to each other. The validity of Assemblages has been fully corroborated by DNA sequence data that, after the introduction of amplification techniques (e.g., PCR), were mainly generated from field isolates (i.e., not expanded by in vitro growth). On the basis of molecular studies of parasites isolated from many hosts, eight Assemblages (A-H) have been described, among which Assemblages A and B infect humans and other animals, Assemblages $C$ and D are restricted to carnivores, Assemblage $\mathrm{E}$ to hoofed animals, Assemblage $\mathrm{F}$ to cats, Assemblage $\mathrm{G}$ to rats, and Assemblage $\mathrm{H}$ to marine mammals (Feng and Xiao, 2011) (Table 2).

Table 2. The currently recognized G. duodenalis Assemblages, their host distribution and proposed taxonomy

\begin{tabular}{|c|c|c|}
\hline Assemblage & Host distribution & Proposed species name \\
\hline A & $\begin{array}{c}\text { Humans and other primates, livestock, dogs, cats, and } \\
\text { some species of wild mammals }\end{array}$ & Giardia duodenalis \\
\hline B & $\begin{array}{l}\text { Humans and other primates, dogs, cats, and some species } \\
\text { of wild mammals }\end{array}$ & Giardia enterica \\
\hline $\mathrm{C}$ & Dogs and other canids & Giardia canis \\
\hline $\mathrm{D}$ & Dogs and other canids & Giardia canis \\
\hline $\mathrm{E}$ & Hoofed livestock & Giardia bovis \\
\hline $\mathrm{F}$ & Cats & Giardia cati \\
\hline G & Rats & Giardia simondi \\
\hline $\mathrm{H}$ & Marine mammals (pinnipeds) & NR \\
\hline
\end{tabular}

NR - Not Reported 
The genetic differences separating the eight Assemblages are very large, paralleled by phenotypic differences in terms of adaptability to in vitro culture, metabolism, and susceptibility to drugs, and to infection with a double stranded RNA virus (Thompson and Monis, 2012). Finally, comparisons at the whole genome level have reinforced the concept that Assemblages represent distinct species (Adam et al., 2013).

Therefore, it has been proposed (Monis et al., 2009) that the different Assemblages deserve the status of species, and that previously assigned names are available for most Assemblages (Table 2). However, controversial points remain, mostly concerning the names to be given to the human-associated Assemblages A and B (the proposed names are G. duodenalis and G. enterica, respectively).

\subsection{Transmission}

Humans acquire infection by ingestion of the cysts via direct contact with feces from other infected persons (anthroponotic transmission), animals (zoonotic transmission), or by ingestion of contaminated food or water (foodborne or waterborne transmission). Doseresponse has been well established and used for estimating risk with the ID50 (dose causing 50\% infection in those exposed) at $\quad 35 \quad$ cysts. (http://qmrawiki.canr.msu.edu/index.php?title=Table_of_Re commended_Best-Fit_Parameters \# tab=Protozoa) (Rendtorff, 1954)

\subsubsection{Transmission routes}

Human to human transmission via feces is an essential element in the epidemiology of giardiasis. Direct transmission occurs most commonly in environments where hygiene levels are compromised, such as child day-care centres or in disadvantaged community settings. The rising incidence in such settings has led to the designation of giardiasis as a re-emerging infectious disease in the developed world (Savioli et al., 2006).

The issue of zoonotic transmission of giardiasis has dominated the debate for about 30 years, since the WHO first recognized giardiasis as a zoonosis. Pets and livestock, along with some wild animals, have long been considered as the likely reservoirs (Feng and Xiao, 2011). Molecular epidemiologic surveys have demonstrated that host-specific Giardia duodenalis Assemblages are more common in their respective hosts than zoonotic Assemblages. Nevertheless, Assemblage A and, more occasionally, Assemblage B have been identified in many animal species (Ryan and Cacciò, 2013). It has been argued that studies in defined endemic areas, where transmission dynamics and host range are known, should provide a better understanding of the significance of animals as reservoirs and conditions where zoonotic transmission can occur (Thompson and Monis, 2012). However, studies in Australia, Peru, India, and Thailand generated controversial results, with some supporting zoonotic transmission (from dogs to humans) while others found no support (Ryan and Cacciò, 2013). Nevertheless, there is a tendency to consider that the zoonotic risk posed by Giardia isolates from pets, livestock and wild animals is low, but it cannot be excluded from current data (Ryan and Cacciò, 2013).

Waterborne transmission also plays a very important role in the epidemiology of human giardiasis, worldwide. A recent review reported that, of the 199 global outbreaks caused by protozoa during the period 2004-2010, 70 (35\%) were caused by Giardia(Baldursson and Karanis, 2011). The majority of these outbreaks were reported from North America, UK, and Asia (Robertson and Lim, 2014); this is likely the result of better detection and monitoring systems rather than epidemiological differences in various parts of the world. Outbreaks can be large, as was the case of the Bergen (Norway) outbreak of 2004, with a total of 1300 laboratory confirmed cases (Nygård et al., 2006). The water treatment plant involved in this outbreak was one of the oldest in Norway and the treatment in place during the outbreak was just chlorination. Leaking sewage pipes contaminating the drinking water supply combined with insufficient water treatment was the likely cause of the outbreak.

In the US, in the period from 1971 to 2011, 242 outbreaks of giardiasis were reported to the Centers for Disease Control and Prevention (Adam et al, 2016). These outbreaks affected $\sim 41,000$ persons, and resulted from waterborne $(74.8 \%)$, foodborne $(15.7 \%)$, person-to-person $(2.5 \%)$, and animal contact $(1.2 \%)$ transmission. Most waterborne outbreaks were associated with drinking water (74.6\%), followed by recreational water (18.2\%).

Foodborne transmission has been more difficult to prove. Natural contamination with Giardia cysts has been demonstrated for fruits (strawberries), vegetables (dill, lettuce, basil, mung bean sprouts and radish sprouts) and shellfish (species of oysters, mussels and clams) (Escobedo et al., 2010; Adell et al. 2014). This finding has public health implications because these products are frequently consumed raw without thermal processing. Voluntary consumption of mud or sand (geophagia), which is particularly common in children and individuals with mental problems, may also contribute to the transmission of Giardia(Giacometti et al., 1997). Factors contributing to under-reporting of foodborne outbreaks include the lack of appropriate diagnostic tools and the fact that foodborne outbreaks may be more widespread than waterborne outbreaks, thus appearing sporadic. Most foodborne outbreaks of giardiasis have been ascribed to direct contamination of food by a food handler.

\subsubsection{Reservoirs}

Giardia duodenalis is able to infect a wide range of hosts (Table 2), mostly mammals. The prevalence of infection is particularly high among pets, with estimates of $10 \%$ in well-cared-for dogs, $36-50 \%$ in puppies and kittens, and up to $100 \%$ in breeding establishments and kennels (Ballweber et al., 2010). In food production animals, prevalence at the farm level varies between $45 \%$ and $100 \%$. The cumulative incidence on a farm is $100 \%$ in cattle and goats and close to $100 \%$ in sheep, implying that every animal on that farm will get infected (Geurden et al., 2010). Some wild animals, such as beaver and nutria, are often 
infected with Giardia and have been considered important reservoirs of cysts infectious to humans.

Considering the high number of cysts that can be excreted by infected animals (ranging from $10^{1}$ to $10^{6}$ cysts/gram), particularly by young animals, they are considered as an important source of environmental contamination. However, the actual role of animals in the transmission of giardiasis to humans remains uncertain (Feng and Xiao, 2011).

\subsubsection{Incubation period}

The incubation, or pre-patent period, before cysts appear in the faeces, may be short in both humans and other animals, commencing as early as 3 days postinfection, but can range up to 3 weeks depending upon host species Assemblage, infectious dose, host immune responses, and other host factors.

\subsubsection{Period of communicability}

The duration of infection may vary from a few days to several months. The first appearance of any symptoms usually coincides with the onset of cyst excretion. Cyst excretion is characteristically intermittent in both humans and other animal species, and cysts are resistant to various environmental stressors and thus can survive for at least 2 months in suitable temperature and moisture conditions.

\subsubsection{Population susceptibility}

In humans, giardiasis is mainly a pediatric infection, with the highest prevalence observed in children aged 1-4 years. This is true for both industrialized and developing countries, and is thought to be due to lower hygiene and higher susceptibility of children (with immature immune system) at the first exposure to the parasite (Cacciò and Sprong, 2014). A secondary peak is observed in adults aged 30-40; in this case, women represent the risk category, likely because of direct transmission of the parasite from children to their mothers. Other risk groups include institutionalized children in developing and developed countries, returning travelers from developing countries, immigrant/refugees and adopted children from endemic areas (Cacciò and Sprong, 2011; Escobedo et al, 2010).

Giardiasis is not considered an opportunistic parasitic infection, because no prolonged, or more severe, symptoms are observed in HIV-infected patients, and therapy is independent of immune status. A prevalence between 1.5\% and $17.7 \%$ is reported in a few published studies of HIV patients (Stark et al., 2009).

\subsection{Population and Individual Control Measures}

\subsubsection{Hygiene measures}

Prevention at the individual level is mainly based on good hygienic practices, such as frequent hand washing with soap and avoiding contact with the feces from infected persons or animals. A recent meta-analysis evaluated the effect of various interventions (hygiene, sanitation, water supply, water quality, and multiple interventions) on the reduction of diarrhoeal diseases in developing countries (Fewtrell et al., 2005). Some of the studies considered focused on Giardia. All of the above-mentioned interventions significantly reduced the risks of diarrhea, with a similar degree of impact. Interventions on water quality (e.g., point-of-use water treatment) were found to be more effective. The importance of personal hygiene is further stressed by the role played by infected food handlers in foodborne outbreaks.

A recent study that investigated factors involved in episodes of gastroenteritis in child day-care centres found that disinfecting fomites with chlorine, cleaning vomit with paper towels (and cleaner), daily cleaning of bed linen/toys, formal policies for cohorting and exclusion for ill children and staff, were all protective factors (Enserink et al., 2015). Travelers in countries where giardiasis is endemic should drink bottled water, avoid consuming raw fruits and vegetables, and minimize exposure to untreated water (lakes, rivers and streams). Public health measures are also necessary to protect water supplies against contamination by human or animal feces.

\subsubsection{Drug therapy}

Although giardiasis is usually a self-limiting disease, treatment of confirmed cases is necessary to cure symptoms and shorten the duration of acute infection, therefore reducing the risk of post-infectious complications and prolonged excretion of infectious cysts. The value of treatment in hyperendemic communities is questionable, due to the high rate of re-infection (Gilman et al., 1988).

Six classes of drugs are approved for treatment of giardiasis, including 5-nitroimidazole and benzimidazole derivatives, quinacrine, furazolidone, nitazoxanide and paromomycin (Lalle, 2010). Treatment is usually the same for both immunocompetent and immunosuppressed patients. Among nitroimidazoles, metronidazole (MTZ; Flagyl) is the most commonly used, with a cure rate of $80-95 \%$. The recommended dose of MTZ is $500 \mathrm{mg}$ every 8 hours for 7-10 days, or $2 \mathrm{~g}$ for 3-5 days. MTZ is effective on trophozoites but has no effect on the viability of cysts. Side effects include gastrointestinal upset, headache, nausea, leukopenia, and a metallic taste in the mouth. In about $10-20 \%$ of the clinical cases, resistance to MTZ has been reported, with recurrence rates of up to $90 \%$.

Other 5-nitroimidazole drugs are available with less side effects compared to MTZ and are optimized for single daily-dose therapies. Tinidazole (Fasigyn) proved to be $100 \%$ successful against Giardia in a single oral dosage of 2 $\mathrm{g}$ or $50 \mathrm{mg} / \mathrm{kg}$. Secnidazole (Flagentyl) administrated in a single oral dose of $2 \mathrm{mg}$ achieves clinical/parasistological cure rates of $80-100 \%$, whereas ornidazole (Tiberal) is generally administrated as a single dose but for several days and can achieve 100\% effectiveness.

In the case of treatment failure of first line drugs, other nitro-drugs can be used. The synthetic nitrofuran furazolidone (Furoxone) is administered as four doses per 
day in adults (100 $\mathrm{mg}$ per dose) and children $(1.5 \mathrm{mg} / \mathrm{kg})$, and a cure rate of $80-96 \%$ has been reported for 7-10-day treatment courses. In about $10 \%$ of cases, gastrointestinal disturbance, nausea, vomiting, diarrhoea, malaise, itch, urticaria, hypersensitivity, and haemolysis in glucose-6phosphate dehydrogenase-deficient patients, have been reported.

Nitazoxamide (Alinia or Annita) is a synthetic nitrothiazolyl-salicylamide derivative discovered in the 1980 s as an anti-helminthic and later found to be active against Giardia and other intestinal protozoa. The drug is approved in the US for the treatment of both cryptosporidiosis and giardiasis in immunocompetent individuals. The recommended dose is $500 \mathrm{mg}$ twice a day for 3 days, with an $85 \%$ clinical cure and $71-80 \%$ parasite eradication observed in patients. This drug is also well tolerated with few gastrointestinal side effects.

Benzimidazoles such as the benzimidazole carbamate compound albendazole, fenbendazole and mebendazole, exert a good anti-giardial efficacy along with anti-helmintic activity. Treatment of patients with albendazole is less efficacious than treatment with MTZ, with a 62 to $95 \%$ average efficacy of albendazole compared to $97 \%$ for MTZ. Side effects for benzimidazoles are similar, but less intense, to those reported for MTZ.

In cases of seriously refractory giardiasis, acridine yellow quinacrine can be used. The drug was first used as an antimalarial but have been found to also be effective against Giardia, with a reported cure rate of $92-95 \%$. However, quinacrine can cause serious side effects including dizziness, headache, vomiting, psychotic response, reproductive tract cancers, development of abnormal uterine lesions, ectopic pregnancy, prolonged amenorrhea, and fetal exposure.

During pregnancy, paromomycin is considered the safest drug to treat giardiasis, especially during the first trimester. Paromomycin sulfate is a broad-spectrum aminoglycoside antibiotic with a $60-70 \%$ efficacy against giardiasis. Since paromomycin is poorly absorbed after oral administration, the drug does not reach the fetus. Nausea, increased gastrointestinal motility, abdominal pain, and diarrhea are the most common side effects, and like other aminoglycosides, systemic absorption of this antibiotic may cause ototoxicity and nephrotoxicity.

\subsection{Environmental Occurrence and Persistence}

Technological advances for detection and surveillance of waterborne pathogens have allowed for a better understanding of their global occurrence. Giardia cysts have been recovered from several environmental matrices, including watersheds used as a source of drinking water or for recreational activities, in both high and low income areas. In addition to water, cysts have been detected in other samples such as sewage, sludge, and soil. All types of ambient water bodies are vulnerable to contamination by Giardia through either land runoff or discharge of wastewater and sewage. The high numbers of infective cysts excreted in feces of a wide range of hosts and their ability to survive in the environment clearly increase dispersion and transmission. Many countries have legislation or follow guidelines for source water quality and environmental protection, yet Giardia continues to be one of the major causes of waterborne disease outbreaks. Thus, a better knowledge on environmental contamination by cysts including occurrence, persistence, and survival data would enhance our understanding of the epidemiology and help to establish public health priorities and preventive measures.

\subsection{Detection Methods}

Detection of Giardia cysts in the environment, particularly in aquatic systems, requires sensitive and specific methods. Efficient detection is complicated by many interfering factors, including the small size and dispersion of cysts in the environment and the presence of high amounts of interfering extraneous particulate materials (Carmena, 2010). A universally adopted method is not available, but the United States Environmental Protection Agency (USEPA 1623) (USEPA, 2005) has been widely used in different studies and became a standard for the simultaneous detection, identification, and enumeration of Giardia cysts and Cryptosporidium oocysts in environmental samples.

USEPA 1623 method is based on the following key steps: (1) filtration, usually of volumes between 10 and 1000 L; (2) concentration; (3) immunomagnetic separation (IMS) using magnetizable beads coated with specific antibodies; and (4) detection/enumeration by immunofluorescence assay (IFA) by epi-fluorescence microscopy (Skotarczak et al., 2009; Ramirez-Castillo et al., 2015). Since its introduction in 1996, a number of revisions have been proposed (USEPA Method 1623.1 EPA 816R-12-001; Rhodes et al., 2012), particularly with regard to sample filtration and immunomagnetic separation, and different kinds of filters and IMS kits have been tested and validated for use (Skotarczak et al., 2009).

Despite various limitations, such as high cost, low recovery efficiency and the necessity of well-trained personnel, the IMS/IFA approach is widely used to detect Giardia cysts in water and other environmental samples. A number of factors, including the filtration system and the physicochemical and organic properties of the sample, such as turbidity, $\mathrm{pH}$, inorganic compounds and suspended algae, are known to influence the recovery efficiency (Carmena, 2010). Alternative techniques have been proposed, including fluorescently activated cell sorting (FACS), which has high sensitivity and specificity, being also amenable to high throughput. However, high cost, difficult-to-operate cell sorters and challenges in processing turbid samples and have prevented its routine application (Health Canada, 2012).

Protocols for routine detection of Giardia in the environmental samples, including the USEPA 1623 method, are microscopy-based. Therefore, their use do not consent to determine the species and genotypes of the recovered cysts, which is necessary to infer their likely origin (humanderived versus animal-derived) and generate data useful to 
track the source of pollution/contamination in environmental samples (Skotarczak et al., 2009; RamirezCastillo et al., 2015). The accurate identification and characterization of Giardia cysts can be obtained using molecular methods, of which those based on the Polymerase Chain Reaction (PCR) are the most widely used. A variety of PCR assays have been described, including conventional PCR, reverse transcriptase PCR (RT-PCR), real-time PCR (qPCR) and multiplex-PCR (mPCR). Depending on the PCR assays used above, they can amenable for indirect detection of viable cysts (RT-PCR), for quantitative evaluation of cyst number (qPCR), and for simultaneous detection of Giardia and other organisms in sample (qPCR and mPCR). These methods usually have high sensitivity and specificity, but their performance on environmental samples is influenced by the presence of inhibitors that can suppress or reduce the amplification efficiencies; thus, strategies to remove or minimize PCR inhibitors during nucleic acid preparation steps are essential to ensure optimal method performance
(Skotarczak et al., 2009). Other molecular methods used for cyst detection are loop-mediated isothermal amplification (LAMP) and fluorescence in situ hybridization (FISH). LAMP is less affected by the presence of inhibitors, does not require thermal cyclers and has a low cost, whereas FISH allows enumeration and an indirect assessment of cyst viability.

\subsection{Data on Occurrence}

\subsubsection{Raw sewage and sludge}

Investigations of raw sewage (influent) and outgoing wastewater (treated/final effluent) have provided information on the presence of pathogens in a given population and on pathogen reduction resulting from treatment plant operation, respectively. A number of surveys have shown the frequent and ubiquitous presence of Giardia cysts in raw sewage influents and effluents samples from wastewater treatment plants (Table 3).

Table 3. Occurrence of Giardia cysts in raw sewage influent and treated effluent samples from wastewater treatment plants

\begin{tabular}{|c|c|c|c|c|}
\hline Area & $\begin{array}{l}\text { Sample } \\
\text { Type }\end{array}$ & $\begin{array}{c}\text { Percent Positive } \\
\text { (\# of samples) } \\
\text { See footnotes a, b, c for } \\
\text { method used }\end{array}$ & $\begin{array}{c}\text { Concentration Average (range), } \\
\text { Cysts/L }\end{array}$ & Reference \\
\hline \multicolumn{5}{|c|}{ Raw Sewage Influents } \\
\hline Brazil & Influent & $\begin{array}{l}90.5 \%{ }^{\mathrm{c}} \\
(48 / 53)\end{array}$ & $1.0 \mathrm{E}+05$ (Mean) & Neto et al., 2006 \\
\hline Brazil & Influent & $\begin{array}{l}100.0 \%{ }^{\mathrm{a}} \\
(24 / 24)\end{array}$ & 30 to $1.9 \mathrm{E}+04$ & $\begin{array}{l}\text { Hachich et al., } \\
2013\end{array}$ \\
\hline Canada & Influent & $\begin{array}{l}95.0 \%^{\mathrm{a}} \\
(18 / 19)\end{array}$ & $9.0 \mathrm{E}+03(\max )$ & $\begin{array}{l}\text { Lalancette et al., } \\
\qquad 2012\end{array}$ \\
\hline China & Influent & $\begin{array}{l}100.0 \%^{\mathrm{a}} \\
(33 / 33)\end{array}$ & $1.3 \mathrm{E}+02$ to $3.6 \mathrm{E}+03$ & Fu et al., 2010 \\
\hline Germany & Influent & $\begin{array}{c}88.0 \%^{\mathrm{a}} \\
(120 / 155)\end{array}$ & 50 to $7.5 \mathrm{E}+03$ & Ajonina et al., 2013 \\
\hline Greece & Influent & $\begin{array}{c}18.9 \%^{\mathrm{d}} \\
(7 / 37)\end{array}$ & NR & $\begin{array}{l}\text { Spanakos et al., } \\
2015\end{array}$ \\
\hline Italy & Influent & $\begin{array}{l}100.0 \% \\
(16 / 16)\end{array}$ & $2.1 \mathrm{E}+03$ to $4.2 \mathrm{E}+04$ & Cacciò et al., 2003 \\
\hline $\begin{array}{l}\text { Ivory } \\
\text { Coast }\end{array}$ & Influent & $\begin{array}{l}83.0 \% \\
(20 / 24)\end{array}$ & $\begin{array}{c}1.5 \mathrm{E}+01 \\
(\text { Mean })\end{array}$ & Yapo et al., 2014 \\
\hline Japan & Influent & $\begin{array}{c}100.0 \%{ }^{\mathrm{a}} \\
(24 / 24)\end{array}$ & $3.7 \mathrm{E}+02$ to $3.9 \mathrm{E}+03$ & Oda et al., 2005 \\
\hline Malaysia & Influent & $\begin{array}{c}100.0 \% \\
(24 / 24)\end{array}$ & 4 to $8.5 \mathrm{E}+03$ & Lim et al., 2007 \\
\hline Norway & Influent & $\begin{array}{l}93.0 \%{ }^{\mathrm{a}, \mathrm{e}} \\
(37 / 40)\end{array}$ & $1.0 \mathrm{E}+02$ to $1.4 \mathrm{E}+04$ & $\begin{array}{l}\text { Robertson et al., } \\
2006\end{array}$ \\
\hline $\begin{array}{l}\text { South } \\
\text { Africa }\end{array}$ & Influent & $\begin{array}{l}82.0 \%^{\mathrm{a}, \mathrm{e}} \\
(46 / 56)\end{array}$ & 1 to $4.5 \mathrm{E}+03$ & $\begin{array}{l}\text { Dungeni \& Momba, } \\
2010\end{array}$ \\
\hline $\begin{array}{l}\text { South } \\
\text { Africa }\end{array}$ & Influent & $\begin{array}{l}31.6 \%{ }^{\mathrm{a}, \mathrm{e}} \\
(25 / 79)\end{array}$ & NR & Samie et al., 2014 \\
\hline Spain & Influent & $\begin{array}{l}91.0 \%{ }^{\mathrm{b}} \\
(10 / 11)\end{array}$ & 9.8 to $1.8 \mathrm{e}+03$ & $\begin{array}{l}\text { Gomez-Couso et al., } \\
2005\end{array}$ \\
\hline
\end{tabular}




\begin{tabular}{|c|c|c|c|c|}
\hline Area & $\begin{array}{l}\text { Sample } \\
\text { Type }\end{array}$ & $\begin{array}{c}\text { Percent Positive } \\
\text { (\# of samples) } \\
\text { See footnotes a, b, c for } \\
\text { method used }\end{array}$ & $\begin{array}{c}\text { Concentration Average (range), } \\
\text { Cysts/L }\end{array}$ & Reference \\
\hline Spain & Influent & $\begin{array}{l}98.0 \%^{\mathrm{a}} \\
(49 / 50)\end{array}$ & 2 to $1.4 \mathrm{E}+04$ & $\begin{array}{l}\text { Castro-Hermida et } \\
\text { al., } 2010\end{array}$ \\
\hline Spain & Influent & $\begin{array}{l}100 \%{ }^{d} \\
(26 / 26)\end{array}$ & 67 & Reinoso et al., 2011 \\
\hline Spain & Influent & $\begin{array}{c}100.0 \%{ }^{b} \\
(13 / 13)\end{array}$ & NR & $\begin{array}{l}\text { Rodriguez-Manzano } \\
\text { et al., } 2012\end{array}$ \\
\hline Tunisia & Influent & $\begin{array}{l}80.0 \%{ }^{\mathrm{a}, \mathrm{g}} \\
(6 / 7)\end{array}$ & $6.6 \mathrm{E}+01$ to $3.2 \mathrm{E}+02$. & Khouja et al., 2010 \\
\hline USA & Influent & $\begin{array}{c}55.3 \% \%^{\mathrm{a}, \mathrm{e}} \\
(131 / 237)\end{array}$ & NR & $\begin{array}{l}\text { Sulaiman et al., } \\
2004\end{array}$ \\
\hline USA & Influent & $\begin{array}{l}100.0 \%^{\mathrm{a}} \\
(30 / 30)\end{array}$ & 5.0E+02 (Max) & $\begin{array}{l}\text { Harwood et al., } \\
2005\end{array}$ \\
\hline USA & Influent & $\begin{array}{l}100.0 \%^{\mathrm{a}} \\
(23 / 24)\end{array}$ & $1.4 \mathrm{E}+03$ to $1.5 \mathrm{E}+04$ & $\begin{array}{l}\text { Kitajima et al., } \\
2014\end{array}$ \\
\hline \multicolumn{5}{|c|}{ Treated Sewage Effluents } \\
\hline Brazil & $\begin{array}{l}\text { Activated Sludge } \\
\text { Effluent }\end{array}$ & $\begin{array}{l}95.6 \%{ }^{\mathrm{c}} \\
(87 / 91)\end{array}$ & $\begin{array}{l}1.1 \mathrm{E}+03 \\
(\text { Mean) }\end{array}$ & Neto et al., 2006 \\
\hline Brazil & $\begin{array}{l}\text { Activated Sludge } \\
\text { Effluent }\end{array}$ & $\begin{array}{l}79.2 \%^{\mathrm{a}} \\
(19 / 24)\end{array}$ & $5.0 \mathrm{E}-02$ to $1.1 \mathrm{E}+02$ & $\begin{array}{l}\text { Hachich et al., } \\
2013\end{array}$ \\
\hline Bulgaria & Effluent & $\begin{array}{c}42.9 \%^{\mathrm{b}} \\
(3 / 7)\end{array}$ & $11.4 \mathrm{E}+02$ to $6.0 \mathrm{E}+2$ & Karanis et al., 2006 \\
\hline Canada & $\begin{array}{l}\text { Activated Sludge } \\
\text { Effluent }\end{array}$ & $\begin{array}{l}61.0 \%{ }^{\mathrm{a}} \\
(11 / 18)\end{array}$ & 4.7E+02 (Max) & $\begin{array}{l}\text { Lalancette et al., } \\
\qquad 2012\end{array}$ \\
\hline China & $\begin{array}{l}\text { Activated Sludge } \\
\text { Effluent }\end{array}$ & $\begin{array}{l}100.0 \%^{\mathrm{a}} \\
(33 / 33)\end{array}$ & 0 to $2.0 \mathrm{E}+03$ & Fu et al., 2010 \\
\hline China & $\begin{array}{l}\text { anaerobic-anoxic-oxic } \\
\text { (AAO) process }\end{array}$ & $\begin{array}{l}96.0 \%{ }^{\mathrm{a}, \mathrm{f}} \\
(48 / 50)\end{array}$ & 0 to 49 & Ma et al., 2016 \\
\hline China & $\begin{array}{l}\text { Membrane } \\
\text { bioreactor }\end{array}$ & $\begin{array}{c}100.0 \%^{\mathrm{a}, \mathrm{e}} \\
(12 / 12)\end{array}$ & 3 to 95 & Zhang et al., 2015 \\
\hline Germany & $\begin{array}{c}\text { Activated Sludge } \\
\text { Effluent }\end{array}$ & $\begin{array}{c}88.0 \%^{\mathrm{a}} \\
(120 / 155)\end{array}$ & 30 to $3.2 \mathrm{E}+03$ & Ajonina et al., 2013 \\
\hline Greece & $\begin{array}{l}\text { Activated Sludge } \\
\text { Effluent }\end{array}$ & $\begin{array}{l}5.6 \%{ }^{\mathrm{d}} \\
(2 / 36)\end{array}$ & NR & $\begin{array}{l}\text { Spanakos et al., } \\
2015\end{array}$ \\
\hline Malaysia & $\begin{array}{l}\text { Extended Aeration } \\
\text { Aerated Lagoon } \\
\text { Effluent }\end{array}$ & $\begin{array}{l}62.5 \%{ }^{b} \\
(15 / 24)\end{array}$ & 1 to $1.5 \mathrm{E}+03$ & Lim et al., 2007 \\
\hline Norway & $\begin{array}{l}\text { Activated Sludge } \\
\text { Effluent }\end{array}$ & $\begin{array}{l}74.0 \%^{\mathrm{a}} \\
(53 / 72)\end{array}$ & $1.0 \mathrm{E}+02$ to $5.1 \mathrm{E}+04$ & $\begin{array}{l}\text { Robertson et al., } \\
2006\end{array}$ \\
\hline Poland & $\begin{array}{l}\text { Activated Sludge } \\
\text { Effluent }\end{array}$ & $\begin{array}{l}84.6 \% \\
(11 / 13)\end{array}$ & 0.7 to 66 & Sroka et al., 2013 \\
\hline $\begin{array}{l}\text { South } \\
\text { Africa }\end{array}$ & $\begin{array}{l}\text { Activated Sludge } \\
\text { Effluent }\end{array}$ & $\begin{array}{l}67.9 \%^{\mathrm{a}, \mathrm{e}} \\
(38 / 56)\end{array}$ & 1 to $1.7 \mathrm{E}+02$ & $\begin{array}{c}\text { Dungeni \& Momba, } \\
2010\end{array}$ \\
\hline $\begin{array}{l}\text { South } \\
\text { Africa }\end{array}$ & $\begin{array}{l}\text { Activated Sludge } \\
\text { Effluent }\end{array}$ & $\begin{array}{l}31.6 \%{ }^{\mathrm{a}, \mathrm{e}} \\
(25 / 79)\end{array}$ & NR & Samie et al., 2014 \\
\hline Spain & $\begin{array}{l}\text { Activated Sludge } \\
\text { Effluent }\end{array}$ & $\begin{array}{l}87.5 \%{ }^{b} \\
(14 / 16)\end{array}$ & 7 to $2.5 \mathrm{E}+03$ & $\begin{array}{l}\text { Gomez-Couso et al., } \\
2005\end{array}$ \\
\hline Spain & Undescribed & $\begin{array}{l}96.0 \%{ }^{\mathrm{a}} \\
(48 / 50)\end{array}$ & 2 to $6.0 \mathrm{E}+03$ & $\begin{array}{c}\text { Castro-Hermida et } \\
\text { al., } 2010\end{array}$ \\
\hline Spain & $\begin{array}{l}\text { Waste Stabilization } \\
\text { ponds } \\
\text { Anaerobic, } \\
\text { facultative \& } \\
\text { maturations }\end{array}$ & $\begin{array}{l}73.0 \%{ }^{d} \\
(19 / 26)\end{array}$ & $\begin{array}{c}8.1 \\
2.4 \& \\
0.7 \\
\text { (means) }\end{array}$ & Reinoso et al., 2011 \\
\hline Spain & $\begin{array}{l}\text { Activated Sludge } \\
\text { Effluent }\end{array}$ & $\begin{array}{l}83.3 \%{ }^{b} \\
(10 / 12)\end{array}$ & 0.4 to 13.2 & $\begin{array}{c}\text { Rodriguez-Manzano } \\
\text { et al., } 2012\end{array}$ \\
\hline
\end{tabular}




\begin{tabular}{lcccc}
\hline Area & $\begin{array}{c}\text { Sample } \\
\text { Type }\end{array}$ & $\begin{array}{c}\text { Percent Positive } \\
\text { (\# of samples) } \\
\text { See footnotes a, b, c for } \\
\text { method used }\end{array}$ & $\begin{array}{c}\text { Concentration Average (range), } \\
\text { Cysts/L }\end{array}$ & Reference \\
\hline USA & $\begin{array}{c}\text { Activated Sludge } \\
\text { Effluent }\end{array}$ & $80.0 \%$ & NR & Harwood et al., \\
2005 & Kitajima et al., \\
USA & Undescribed & $\begin{array}{c}96.0 \%{ }^{\mathrm{a}} \\
(23 / 24)\end{array}$ & $<0.4$ to $6.2 \mathrm{E}+02$ & 2014
\end{tabular}

\section{NR - Not Reported}

Methods used ${ }^{\mathrm{a}}$ IMS-IFA, ${ }^{\mathrm{b}}$ IFA, ${ }^{\mathrm{c}}$ filtration and IFA, ${ }^{\mathrm{d}}$ flocculation and IFA

G. duodenalis ${ }^{\mathrm{e}}$ Assemblages A and B, ${ }^{\mathrm{f}}$ Assemblage AII, ${ }^{\mathrm{g}}$ Assemblages AI, AII and B

High prevalence rates of Giardia in raw wastewater were reported in both developed and developing countries. Surveys undertaken in North America (Harwood et al., 2005; Kitajima et al., 2014), Europe (Cacciò et al., 2003; Reinoso et al., 2011; Rodriguez-Manzano et al., 2012), Asia (Oda et al., 2005; Lim et al., 2007; Fu et al., 2010; Ma et al., 2016) and South America (Hachich et al., 2013) reported the presence of cysts in up to $100 \%$ of the raw sewage influent samples tested. The number of cysts /L of raw sewage was found to vary from hundreds to thousands. For example, very high numbers were reported in Italy (Cacciò et al., 2003) and in the United States (Kitajima et al., 2014) where cysts were detected at concentrations ranging, from $2.1 \times 10^{3}$ to $4.2 \times 10^{4}$ cysts/L and from $1.4 \times 10^{3}$ to $1.5 \times 10^{4}$ cysts/L, respectively. Similarly, in Norway (Robertson et al., 2006) and Spain (Castro-Hermida et al., 2010), high numbers of cysts were found in raw sewage influent samples that contained from $10^{2}$ to $1.36 \times 10^{4} \mathrm{cysts} / \mathrm{L}$ and 2 to $1.44 \times 10^{4}$ cysts/L. In Brazil, cysts were detected at concentrations as high as $10^{5} \mathrm{cyst} / \mathrm{L}$ (Neto et al., 2006; Hachich et al., 2013). In contrast, relatively few studies have reported cysts at concentrations not exceeding 100 cysts/L (Reinoso et al., 2011; Yapo et al., 2014; Zhang et al., 2015). These data underscore the variability in cyst concentration in influent samples, which is likely influenced by the source of wastewater (e.g. domestic/agricultural), prevalence, intensity and duration of infection in the contributing population, population size, per capita water consumption, and cyst survival (Stott, 2013). In addition, cysts can be found across the whole year in influent samples, but, occasionally, seasonal variations have also been reported (Cacciò et al., 2003; Oda et al., 2005; Ajonina et al., 2013). Analysis of raw sewage for the presence of cysts has been suggested as a way for surveillance of Giardia infection in a community and to detect possible outbreaks (Jakubowski et al., 1991).

In many countries, the final product of a wastewater treatment plant, i.e. treated effluent, is discharged into receiving streams, rivers, or even ocean. Furthermore, the effluent may be used as reclaimed water for irrigation or potable reuse, as is the case in the USA and Africa (Dahl, 2014; Lahnsteiner and Lempert, 2007). Thus, a major goal of wastewater effluent management is to reduce pathogen load and avoid, or diminish, health risk (Harwood et al.,
2005). Effluents from treatment plants often contain Giardia cysts, with prevalence between $<10$ and $100 \%$ (Table 3). In general, cyst concentration does not exceed $7.0 \times 10^{2}$ cysts/L, but can be as high as $6.0 \times 10^{3}$ cysts/L. In contrast, in a Norwegian survey, some sewage effluent samples showed cyst numbers greater than in the influent samples collected on the same day (Robertson et al., 2006). The authors suggested this was an artifact that may depend on (i) higher recovery of cyst from (cleaner) effluent samples, (ii) temporal fluctuations in parasite concentrations, (iii) lack of pairing the samples, (iv) uneven distribution of cysts in the samples, or a combination of these factors. In general, Giardia cysts have been typically detected in lower numbers in treated effluent than in influent samples. Nevertheless, detection of very low numbers, or no detection, of cysts in wastewaters does not guarantee that effluents are free of parasites, since enumeration and detection methods never allow full recovery or provide infective status of the cysts (Stott, 2013).

In sewage treatment plants, sewage sludge, also referred to as biosolids, is a by-product generated at various stages within the treatment process, in order to remove pollutants before discharging the treated effluent into the environment. This product is a mixture of organic and inorganic compounds, which makes it a valuable, cost effective and sustainable source of nutrients and organic matter that is widely used in agriculture and pasture as fertilizer/soil conditioner (Usman et al., 2012). However, a particular disadvantage and concern of land application of sewage sludge is related to its pollutant load, including a wide range of microbial pathogens (Usman et al., 2012). Thus, pathogen loads in sludge must also be reduced before application to land by appropriate stabilization and hygienization procedures. Unfortunately, sludge treatment is not available at all treatment works, especially smaller plants in developing regions, and thus can be an important issue when considering the risks to human health arising from its use.

Studies conducted in wastewater treatment plants for pathogen detection have demonstrated the presence of Giardia cysts in sewage sludge and its derivatives after various treatment methods (Table 4). 
Table 4. Occurrence of Giardia cysts in sludge.

\begin{tabular}{|c|c|c|c|c|}
\hline Area & Sample Type & $\begin{array}{l}\text { Percent } \\
\text { Positive } \\
\text { (\# of } \\
\text { samples) } \\
\end{array}$ & $\begin{array}{c}\text { Concentration Average } \\
\text { (range) }\end{array}$ & Reference \\
\hline Brazil & $\begin{array}{l}\text { Activated } \\
\text { sludge }\end{array}$ & $\begin{array}{c}100.0 \%^{\mathrm{a}} \\
(8 / 8)\end{array}$ & $\begin{array}{c}4 \mathrm{E}+04 \text { to } \\
1.2 \mathrm{E}+06 \\
\text { Cysts/L }\end{array}$ & $\begin{array}{l}\text { Santos et al., } \\
2004\end{array}$ \\
\hline Brazil & $\begin{array}{l}\text { Activated } \\
\text { sludge }\end{array}$ & $\begin{array}{l}100.0 \%^{\mathrm{a}} \\
(22 / 22)\end{array}$ & $\begin{array}{l}4 \mathrm{E}+04 \text { to } \\
4.4 \mathrm{E}+05 \\
\text { Cysts/L }\end{array}$ & $\begin{array}{l}\text { Rondello } \\
\text { Bonatti et al., } \\
2007\end{array}$ \\
\hline Finland & $\begin{array}{c}\text { Raw and } \\
\text { activated } \\
\text { sludge after } \\
\text { lime } \\
\text { stabilization }\end{array}$ & $\begin{array}{l}20.0 \%{ }^{b} \\
(9 / 44)\end{array}$ & NR & Rimhanen-Finne et al., 2001 \\
\hline Finland & $\begin{array}{c}\text { Compost } \\
\text { samples (10- } \\
\text { week-old), } \\
\text { and } \\
\text { end products }\end{array}$ & $\begin{array}{l}44.0 \% \\
\text { and } \\
35.0 \%{ }^{a}\end{array}$ & $\begin{array}{l}0.6 \text { to } 5 \\
\text { Cysts } / 9 \\
\text { and } \\
0.5 \text { to } 2.8 \\
\text { Cysts } / 9\end{array}$ & Rimhanen-Finne et al., 2004 \\
\hline Ireland & $\begin{array}{c}4 \text { urban } \\
\text { facilities } \\
\text { Activated } \\
\text { sludge and } \\
\text { end products } \\
\text { sewage } \\
\text { sludge cake }\end{array}$ & $\mathrm{NR}^{\mathrm{a}, \mathrm{c}}$ & $\begin{array}{c}5.4 \mathrm{E}+02 \text { to } \\
1.54 \mathrm{E}+03 \\
\text { Cysts/L } \\
\text { and } \\
3.0 \mathrm{E}-03 \text { to } \\
0.114 \\
\text { Cysts/g }\end{array}$ & $\begin{array}{l}\text { Graczyk et al., } \\
2007\end{array}$ \\
\hline Poland & $\begin{array}{l}\text { Sewage } \\
\text { sludge }\end{array}$ & $\begin{array}{l}100.0 \% \%^{\mathrm{a}, \mathrm{c}, \mathrm{d}} \\
\quad(6 / 6)\end{array}$ & $\begin{array}{c}22 \text { to } 32 \\
\text { Cysts/g }\end{array}$ & $\begin{array}{l}\text { Graczyk et al., } \\
2008\end{array}$ \\
\hline Spain & $\begin{array}{l}\text { Sludge from } \\
\text { stabilisation } \\
\text { ponds } \\
\text { anaerobic } \\
\text { and } \\
\text { facultative } \\
\text { ponds }\end{array}$ & $\mathrm{NR}^{\mathrm{a}, \mathrm{d}}$ & $\begin{array}{l}6.8 \mathrm{E}+02 \\
\text { and } \\
12.6 \text { Cysts/g } \\
\text { dry weight }\end{array}$ & $\begin{array}{l}\text { Reinoso et al., } \\
2011\end{array}$ \\
\hline Tunisia & $\begin{array}{l}\text { Sewage } \\
\text { sludge }\end{array}$ & $\begin{array}{l}80.0 \% \text { a,b,e,f } \\
(4 / 5)\end{array}$ & 2.4 Cysts/g & $\begin{array}{l}\text { Khouja et al., } \\
2010\end{array}$ \\
\hline Tunisia & $\begin{array}{c}\text { Dry, } \\
\text { dehydrated } \\
\text { sludge }\end{array}$ & $\begin{array}{l}25.0 \% \%^{\mathrm{b}, \mathrm{g}} \\
(3 / 12)\end{array}$ & NR & $\begin{array}{l}\text { Ben Ayed et al., } \\
2012\end{array}$ \\
\hline USA & $\begin{array}{c}\text { Sewage } \\
\text { Sludge Class } \\
\text { B biosolids } \\
\text { from } 9 \\
\text { facilities } \\
\text { five used } \\
\text { anaerobic } \\
\text { digestion and } \\
\text { three } \\
\text { used aerobic } \\
\text { digestion }\end{array}$ & $\begin{array}{c}97.0 \% \\
(33 / 34)\end{array}$ & $\begin{array}{cc} & 1.2 \mathrm{E}+04( \pm \\
1 . & \mathrm{E}+04 \mathrm{SD}) \\
\text { Avg Cysts/g dry weight }\end{array}$ & $\begin{array}{l}\text { Rhodes et al., } \\
\quad 2015\end{array}$ \\
\hline
\end{tabular}

NR - Not Reported

${ }^{\mathrm{a}} \mathrm{IFA},{ }^{\mathrm{b}} \mathrm{PCR},{ }^{\mathrm{c}}$ Fish, ${ }^{\mathrm{d}}$ Sucrose flotation, ${ }^{\mathrm{e}}$ IMS

As shown in some surveys, a widely used conventional wastewater treatment practice, such as the activated sludge digestion procedure, can itself be a source of environmental cysts (Santos et al., 2004; Rondello Bonatti 
et al., 2007; Graczyk et al., 2007a; Graczyk et al., 2008). High concentrations of Giardia cysts were reported in two studies carried out in Brazil (Santos et al., 2004; Rondello Bonatti et al., 2007) in which cysts were detected in $100 \%$ of the activated sludge samples with concentrations ranging from $4.0 \times 10^{4}$ to $1.2 \times 10^{6} \mathrm{cysts} / \mathrm{L}$. These high concentrations reinforce the necessity of contaminant evaluation before its final use, especially in developing countries where improvements toward a safer use of sludge for land applications are hampered by poor or lack of appropriate legislation. A survey in Ireland showed cysts in activated sludge at levels ranging from $5.4 \times 10^{2}$ to $1.1 \times 10^{3} \mathrm{cysts} / \mathrm{L}$, while in its corresponding end-products (sewage sludge cake) lower concentrations between 3 and $1.14 \times 10^{2} \mathrm{cysts} / \mathrm{g}$ were detected (Graczyk et al., 2007a). A significant reduction of cyst load associated with the treated activated sludge was demonstrated however viable cysts were still detected. It is noteworthy that the observed cyst concentration is of public health concern, considering the low infectious dose. Therefore, even after treatment, sludge might still present a risk. Besides activated sludge, Giardia cysts have also been detected in sludge from stabilization ponds and from treatment based on composting procedures (Rimhanen-Finne et al., 2004; Reinoso et al., 2011). In Spain, cysts were found both in aerobic and facultative ponds with concentrations of $6.8 \times 10^{2}$ and $12.6 \mathrm{cysts} / \mathrm{g}$, respectively (Reinoso et al., 2010), with anaerobic ponds showing better treatment process for removing cysts. In Finland, low numbers of cysts were detected in 44 and $35 \%$ of the sludge samples obtained from sludge that have been composting for 10 weeks and in end-products (30 weeks of composting or after stabilization by quicklime and peat addition), respectively (RimhanenFinne et al., 2004).

Very few studies have been carried out to genetically characterize the cysts found in wastewater and sludge samples. In treatment plant influents and effluents that have been surveyed, Assemblages A and B, both of which are known to infect humans, were found (Cacciò et al., 2003; Sulaiman et al., 2004; Robertson et al., 2006; Dungeni and Momba, 2010; Khouja et al., 2010; Samie and Ntekele, 2014; Zhang et al., 2015). Taken together, the predominance of Assemblage A was noted. Not surprisingly, recent data on molecular characterization of Giardia isolates recovered from sewage sludge have revealed the presence of Assemblages and subtypes that are more frequently associated with human infections (Khouja et al., 2010; Ben Ayed et al., 2012).

In both developed and developing countries, municipal wastewater and its by-products are frequently applied to land. However, in developed countries where regulatory standards are applied, much of the wastewater is properly treated prior to use. In contrast, in developing countries, untreated raw wastewater is often used, mainly for crop irrigation (Pachepsky et al., 2011). In these countries, higher levels of pathogens in irrigation waters have been reported (Thurston-Enriquez et al., 2002). In this study, the occurrence of human pathogenic parasites was investigated in irrigation waters used for food crops in the United States and in some Central American countries, and the average concentrations of Giardia in samples were 5.59 cysts/L and 0.25 cyst/L, respectively.

Despite these observations, to date, there is still no clear evidence that infection with Giardia can be associated with wastewater use in agriculture. However, it has been suggested that exposure to wastewater with high Giardiaconcentrations carries an increased risk for infection among exposed farm workers and their families and consumers of crops that are normally eaten uncooked (Ensink et al., 2006). The study found a significantly increased risk of (asymptomatic) Giardiainfection in wastewater farming households in Pakistan when compared with farming households using regular (non-wastewater) irrigation water. Even though irrigation with reclaimed water decreases food safety and poses a potential source of pathogens in foodborne outbreaks, there is still no clear association with illnesses to the use of wastewater for crop irrigation. Nowadays, considering that the concept of a sustainable world is becoming more and more common, the reuse of wastewater fulfills the aim to reduce environmental pollution and to recycle the organic matter of wastes in soil. Irrigation with raw wastewater is increasing in many areas, particularly in developing countries, where there is parallel increase in urban growth and urban food demands. Thus the systematic treatment of wastewater in communities with growing populations for safe reuse is often problematic. The increasing availability and use of wastewater will generate additional challenges for regulatory agencies charged with minimizing potential impacts on public health and the environment (Qadir et al., 2010).

\subsubsection{Surface water - including recreational water}

Among natural water resources, the risk of Giardia contamination is greater from surface waters. Surveys have demonstrated the presence of cysts in rivers, lakes, streams, reservoirs, canals, and others matrices used as a source of drinking water or for recreational activities (Table $5)$. Although most surveys have been conducted in developed countries, recent studies reported cysts detection in surface water samples in South America and Asia. During the last two decades, widespread occurrences of cysts in surface water samples have been demonstrated, with prevalence ranging from $12 \%$ (Robertson \& Gjerde, 2001) to almost 100\% (Anceno et al., 2007; Lim et al., 2008; Mahmoudi et al., 2013), and, in most cases, values greater than $50 \%$. 
Table 5. Occurrence of Giardia cysts in surface water, including recreational water

\begin{tabular}{|c|c|c|c|c|}
\hline Area & $\begin{array}{l}\text { Sample } \\
\text { Type }\end{array}$ & $\begin{array}{c}\text { Percent } \\
\text { Positive } \\
\text { (\# of } \\
\text { samples) }\end{array}$ & $\begin{array}{l}\text { Concentration Average } \\
\text { (range), Cysts/L }\end{array}$ & Reference \\
\hline Belgium & $\begin{array}{l}\text { Raw water } \\
\text { in } \\
\text { catchment } \\
\text { sites }\end{array}$ & $\begin{array}{l}35.0 \%^{\mathrm{a}, \mathrm{d}} \\
(53 / 151)\end{array}$ & 35 (Max) & $\begin{array}{l}\text { Ehsan et al., } \\
2015 a\end{array}$ \\
\hline Belgium & $\begin{array}{l}\text { Swimming } \\
\text { pools, } \\
\text { lakes and } \\
\text { splash } \\
\text { parks }\end{array}$ & $\begin{array}{l}15.2 \%^{\mathrm{a}, \mathrm{d}} \\
(15 / 99)\end{array}$ & $3.0 \mathrm{E}-02$ to 0.7 & $\begin{array}{l}\text { Ehsan et al., } \\
\text { 2015 }\end{array}$ \\
\hline Brazil & $\begin{array}{c}\text { Raw water } \\
\text { treatment } \\
\text { plant }\end{array}$ & $\begin{array}{l}20.0 \%^{a} \\
(3 / 15)\end{array}$ & 0.2 (Mean) & Nishi et al., 2009 \\
\hline Brazil & $\begin{array}{l}\text { Raw water } \\
\text { Watershed } \\
\text { catchments }\end{array}$ & $\begin{array}{c}46.1 \%^{\mathrm{a}} \\
(6 / 13)\end{array}$ & 3.4 (Max) & $\begin{array}{l}\text { Razzolini et al., } \\
2010\end{array}$ \\
\hline Brazil & $\begin{array}{c}\text { Source } \\
\text { water } \\
\text { intake of } \\
\text { treatment } \\
\text { plant }\end{array}$ & $\begin{array}{c}49.5 \%^{\mathrm{a}} \\
(102 / 206)\end{array}$ & 0.1 to 97 & Sato et al., 2013 \\
\hline Bulgaria & Rivers and & $\begin{array}{l}8.5 \% \mathrm{~b} \\
(4 / 47)\end{array}$ & 72 to $1.7 \mathrm{E}+02$ & $\begin{array}{l}\text { Karanis et al., } \\
\quad 2006\end{array}$ \\
\hline Canada & Streams & $\begin{array}{c}46.0 \% \mathrm{~b} \\
(6 / 13)\end{array}$ & $5.0 \mathrm{E}-02$ to 0.6 & $\begin{array}{l}\text { Budu-Amoako et al., } \\
2012\end{array}$ \\
\hline Canada & $\begin{array}{l}\text { Rivers and } \\
\text { source } \\
\text { water } \\
\text { intake of } \\
\text { treatment } \\
\text { plant }\end{array}$ & $\begin{array}{c}44.0 \%{ }^{\mathrm{a}} \\
(107 / 244)\end{array}$ & 0.1 to 97 & Edge et al., 2013 \\
\hline Canada & Rivers & $\begin{array}{l}86.0 \%{ }^{a, e} \\
(98 / 114)\end{array}$ & 38 (Max) & $\begin{array}{l}\text { Prystajecky et al., } \\
2014\end{array}$ \\
\hline China & $\begin{array}{c}\text { Source } \\
\text { water } \\
\text { intake of } \\
\text { treatment } \\
\text { plant }\end{array}$ & $\begin{array}{l}18.0 \%^{\mathrm{a}} \\
(9 / 50)\end{array}$ & 0.1 to 8 & Feng et al., 2011 \\
\hline China & Lake & $\begin{array}{c}65.0 \% \mathrm{a}, \mathrm{c}, \mathrm{e} \\
(37 / 61)\end{array}$ & 3.23 (Max) & Xiao et al., 2013 \\
\hline France & River & $\begin{array}{l}67.0 \%^{\mathrm{a}} \\
(38 / 57)\end{array}$ & 0.1 to 16.5 & Coupe et al., 2006 \\
\hline France & Rivers & $\begin{array}{c}93.8 \%^{\mathrm{a}} \\
(152 / 162)\end{array}$ & $\begin{array}{l}5.0 \mathrm{E}-02 \text { to } \\
51.2\end{array}$ & Mons et al., 2009 \\
\hline France & River & $\begin{array}{l}88.0 \%^{\mathrm{a}} \\
(21 / 24)\end{array}$ & $<2$ E-02 to2.8 & Jacob et al., 2015 \\
\hline Germany & Stream & $\begin{array}{c}4.0 \% \\
(1 / 23)\end{array}$ & 0.67 (Max) & $\begin{array}{l}\text { Gallas-Lindemann } \\
\text { et al., } 2013\end{array}$ \\
\hline Germany & $\begin{array}{l}\text { River and } \\
\text { tributaries }\end{array}$ & $\begin{array}{l}90.0 \% \\
(27 / 30)\end{array}$ & $1.0 \mathrm{E}-02$ to 1.32 & $\begin{array}{l}\text { Kistemann et } \\
\text { al., } 2012\end{array}$ \\
\hline Hungary & $\begin{array}{l}\text { Raw water } \\
\text { from } \\
\text { treatment } \\
\text { plants }\end{array}$ & $\begin{array}{l}48.4 \%^{\mathrm{a}} \\
(15 / 34)\end{array}$ & $\begin{array}{l}5.0 \text { E-02 to } \\
10.3\end{array}$ & $\begin{array}{l}\text { Plutzer et al., } \\
2007\end{array}$ \\
\hline Hungary & $\begin{array}{l}\text { Rivers and } \\
\text { lakes }\end{array}$ & $\begin{array}{l}62.5 \% \%^{\mathrm{a}, \mathrm{f}} \\
(10 / 16)\end{array}$ & 0.1 to 8.5 & $\begin{array}{c}\text { Plutzer et al., } \\
2008\end{array}$ \\
\hline
\end{tabular}




\begin{tabular}{|c|c|c|c|c|}
\hline Area & $\begin{array}{l}\text { Sample } \\
\text { Type }\end{array}$ & $\begin{array}{c}\text { Percent } \\
\text { Positive } \\
\text { (\# of } \\
\text { samples) } \\
\end{array}$ & $\begin{array}{l}\text { Concentration Average } \\
\text { (range), Cysts/L }\end{array}$ & Reference \\
\hline Italy & $\begin{array}{l}\text { River and } \\
\text { water } \\
\text { coúrses in } \\
\text { treatment } \\
\text { facilities }\end{array}$ & $\begin{array}{l}71.0 \% \\
(15 / 21)\end{array}$ & 1E-02 TO 80 & $\begin{array}{l}\text { Briancesco and } \\
\text { Bonadonna, } 2005\end{array}$ \\
\hline Italy & River & $\begin{array}{l}57.0 \% \\
(4 / 7)\end{array}$ & $1 \mathrm{E}-02$ to 0.08 & $\begin{array}{l}\text { Vernile et al., } \\
2009\end{array}$ \\
\hline Italy & $\begin{array}{l}\text { Swimming } \\
\text { pools }\end{array}$ & $\begin{array}{l}38.0 \% \\
(8 / 21)\end{array}$ & NR & $\begin{array}{l}\text { Oliveri et al., } \\
2006\end{array}$ \\
\hline Iran & River & $\begin{array}{r}75.0 \% \\
(15 / 20)\end{array}$ & $3.2 \mathrm{E}+04(\mathrm{Max})$ & $\begin{array}{l}\text { Mahmoudi et al., } \\
2013\end{array}$ \\
\hline Japan & River & $\begin{array}{l}92.0 \% \\
(12 / 13)\end{array}$ & $\begin{array}{c}4.0 \text { E-02 to } \\
0.58\end{array}$ & $\begin{array}{l}\text { Haramoto et al., } \\
2012\end{array}$ \\
\hline Japan & Rivers & $\begin{array}{c}36.0 \%^{\mathrm{a}} \\
(23 / 6423)\end{array}$ & 0.5 to 3.8 & $\begin{array}{l}\text { Haramoto et al., } \\
2012\end{array}$ \\
\hline Malaysia & Rivers & $\begin{array}{l}39.0 \% \\
(68 / 74)\end{array}$ & 0.7 to $1.3 \mathrm{E}+04$ & Lim et al., 2008 \\
\hline Malaysia & Rivers & $\begin{array}{l}30.0 \%{ }^{\mathrm{a}} \\
(18 / 60)\end{array}$ & 0.1 to 12 & $\begin{array}{c}\text { Azman et al., } \\
2009\end{array}$ \\
\hline Malaysia & Lake & $\begin{array}{c}77.8 \%^{\mathrm{a}, \mathrm{h}} \\
(7 / 9)\end{array}$ & 0.17 to 1.1 & $\begin{array}{c}\text { Lim et al., } 2009 \\
\text { Chaidez et }\end{array}$ \\
\hline Mexico & River & $\begin{array}{l}48.0 \%{ }^{\mathrm{a}} \\
(25 / 58)\end{array}$ & 0.17 to 16.33 & al., 2005 \\
\hline Netherlands & $\begin{array}{l}\text { Canals and } \\
\text { rivers }\end{array}$ & $\begin{array}{l}97.0 \% \mathrm{a} \\
(31 / 32)\end{array}$ & 0.1 to 16.7 & $\begin{array}{l}\text { Schets et al., } \\
2008\end{array}$ \\
\hline Netherlands & Lakes & $\begin{array}{l}36.4 \%^{\mathrm{a}} \\
(20 / 55)\end{array}$ & 0.2 to 1.1 & $\begin{array}{l}\text { Schets et al., } \\
2008\end{array}$ \\
\hline Norway & $\begin{array}{l}\text { Rivers and } \\
\text { lakes }\end{array}$ & $\begin{array}{c}11.8 \%^{\mathrm{a}} \\
(48 / 408)\end{array}$ & 0.1 to 0.3 & $\begin{array}{l}\text { Robertson and } \\
\text { Gjerde, } 2001\end{array}$ \\
\hline Philippines & $\begin{array}{l}\text { Rivers, } \\
\text { ponds and } \\
\text { natural } \\
\text { lakes }\end{array}$ & $\begin{array}{l}75.0 \%{ }^{a} \\
(15 / 20)\end{array}$ & 0.1 to 74.4 & $\begin{array}{l}\text { Onichandran et } \\
\text { al., } 2014\end{array}$ \\
\hline Poland & $\begin{array}{l}\text { Rivers, } \\
\text { lakes }\end{array}$ & $\begin{array}{l}60.6 \%{ }^{a} \\
(20 / 33)\end{array}$ & $1.0 \mathrm{E}-03$ to 0.28 & Bajer et al., 2012 \\
\hline Portugal & $\begin{array}{c}\text { Raw water } \\
\text { treatment } \\
\text { plants }\end{array}$ & $\begin{array}{l}58.0 \%^{a, g} \\
(40 / 69)\end{array}$ & NR & Lobo et al., 2009 \\
\hline Portugal & $\begin{array}{c}\text { River } \\
\text { beaches }\end{array}$ & $\begin{array}{l}85.0 \%{ }^{\mathrm{a}} \\
(63 / 74)\end{array}$ & $3.27 \mathrm{E}+02$ & Júlio et al., 2012 \\
\hline Russia & $\begin{array}{c}\text { Source } \\
\text { water } \\
\text { intake of } \\
\text { treatment } \\
\text { plant }\end{array}$ & $\begin{array}{l}26.0 \%{ }^{\mathrm{a}} \\
(26 / 87)\end{array}$ & $\begin{array}{c}2.0 \text { E-02 } \\
\text { (Mean) }\end{array}$ & $\begin{array}{l}\text { Egorov et al., } \\
2002\end{array}$ \\
\hline Russia & $\begin{array}{l}\text { Rivers and } \\
\text { lakes }\end{array}$ & $\begin{array}{c}20.0 \%{ }^{b} \\
(3 / 15)\end{array}$ & 7 to $3.7 \mathrm{E}+02$ & $\begin{array}{l}\text { Karanis et al., } \\
2006\end{array}$ \\
\hline Spain & River & $\begin{array}{c}85.7 \%^{\mathrm{b}} \\
(6 / 7)\end{array}$ & 0.4 to 29.3 & $\begin{array}{c}\text { Gomez-Couso et } \\
\text { al., } 2005\end{array}$ \\
\hline Spain & $\begin{array}{l}\text { Rivers and } \\
\text { reservoirs }\end{array}$ & $\begin{array}{l}77.3 \%^{\mathrm{a}} \\
(68 / 88)\end{array}$ & $\begin{array}{c}2.5 \mathrm{E}+02 \\
(\text { Mean })\end{array}$ & $\begin{array}{c}\text { Carmena et al., } \\
2007\end{array}$ \\
\hline Spain & River & $\begin{array}{c}67.0 \%^{\mathrm{a}, \mathrm{d}} \\
(78 / 116)\end{array}$ & 2 to $7.22 \mathrm{E}+02$ & $\begin{array}{c}\text { Castro-Hermida } \\
\text { et al., } 2009\end{array}$ \\
\hline Switzerland & Streams & $\begin{array}{l}97.5 \% \mathrm{a} \\
(39 / 40)\end{array}$ & $\begin{array}{c}5.0 \text { E-02 to } \\
10.8\end{array}$ & Wicki et al., 2009 \\
\hline
\end{tabular}




\begin{tabular}{|c|c|c|c|c|}
\hline Area & $\begin{array}{l}\text { Sample } \\
\text { Type }\end{array}$ & $\begin{array}{c}\text { Percent } \\
\text { Positive } \\
\text { (\# of }\end{array}$ & $\begin{array}{l}\text { Concentration Average } \\
\text { (range), Cysts/L }\end{array}$ & Reference \\
\hline Taiwan & $\begin{array}{c}\text { Small } \\
\text { water } \\
\text { systems }\end{array}$ & $\begin{array}{l}46.2 \%{ }^{a} \\
(12 / 26)\end{array}$ & $2.9 \mathrm{E}-03$ to 10.3 & Hsu et al., 2001 \\
\hline Thailand & Canals & $\begin{array}{c}98.3 \% \%^{\mathrm{c}, \mathrm{f}} \\
(118 / 120)\end{array}$ & $3.2 \mathrm{E}+04(\mathrm{Max})$ & $\begin{array}{l}\text { Anceno et al., } \\
2007\end{array}$ \\
\hline USA & River & $\begin{array}{c}24.5 \%^{\mathrm{a}} \\
(47 / 192)\end{array}$ & $\begin{array}{l}1.0 \mathrm{E}-03 \text { to } \\
5.8 \mathrm{E}-02\end{array}$ & Ryu et al., 2008 \\
\hline USA & $\begin{array}{l}\text { Swimming } \\
\text { pools }\end{array}$ & $\begin{array}{c}6.9 \%^{\mathrm{c}} \\
(11 / 160)\end{array}$ & NR & $\begin{array}{c}\text { Shields et al., } \\
2008\end{array}$ \\
\hline
\end{tabular}

\section{NR - Not Reported}

${ }^{\mathrm{a}}$ IMS-IFA, ${ }^{\mathrm{b}} \mathrm{IFA},{ }^{\mathrm{c}} \mathrm{PCR} ; \mathrm{G}$. duodenalis ${ }^{\mathrm{d}}$ Assemblages A (AI and AII), B and E, ${ }^{\mathrm{e}}$ Assemblages A, B and E, ${ }^{\mathrm{f}}$ Assemblages A and $\mathrm{B}$,

${ }^{\mathrm{g}}$ Assemblage A( AI), ${ }^{\mathrm{h}}$ Assemblages A

Cyst concentration in surface waters is usually low or moderate, ranging from $<1$ to $2.5 \times 10^{2}$ cysts/L. Low concentrations ( $<1$ to 50 cysts/L) are often reported in the United States and in some European countries, although significantly high number of cysts (from 2 to $7.22 \times 10^{2}$ cysts/L) were detected in river samples from Spain (Castro-Hermida et al., 2009). In developing countries, higher concentrations are more common (up to $3.24 \times 10^{4} \mathrm{cysts} / \mathrm{L}$ ), as represented by studies of water from canals in Thailand (Anceno et al., 2007), and rivers in Malaysia (Lim et al., 2008), and Iran (Mahmoudi et al., 2013).

Furthermore, Giardia cysts have been detected in raw water samples from treatment plants, at levels ranging from $<1$ to 97 cysts/L. This includes studies in Taiwan (Hsu et al., 2001), Russia (Egorov et al., 2002), Italy (Briancesco \& Bonadonna, 2005), Portugal (Lobo et al., 2009), and Brazil (Nishi et al., 2009; Razzolini et al., 2010, Sato et al., 2013).

Molecular methods have not been widely used to identify the Giardia species and genotypes present in contaminated water samples. Based on PCR, the presence of Assemblages AI, AII, B and E was demonstrated in surface waters (Anceno et al., 2007; Plutzer et al., 2008; Castro-Hermida et al., 2009; Lobo et al., 2009; Xiao et al., 2013; Prystajecky et al., 2014, Ehsan et al., 2015a), supporting the fact that both human and animal feces contribute to contaminating these waters.

Taken together, environmental data highlight the importance of establishing adequate protection of surface water worldwide, because most people are supplied by systems that use surface water. Indeed, the lack of, or inadequate, treatment of water sources is the most common deficiency reported from investigations of waterborne giardiasis outbreaks linked to drinking water (Karanis et al., 2007).
Giardia cysts have been found in natural recreational freshwaters such as lakes, rivers and streams (Table 5). In Europe, 15-98\% of samples from rivers and lakes used for bathing or sporting activities contained Giardia cysts (Schets et al., 2008; Wicki et al., 2009; Júlio et al., 2012). Cyst concentration ranged from $<1$ to $3.27 \times 10^{2}$ cyst/L, with the highest level recorded during a very rainy season at a river beach in Portugal, which was close to agricultural lands, livestock farms, and wastewater discharges (Júlio et al., 2012). In developing countries, 30-78\% of samples from recreational lakes and rivers in Malaysia contained Giardia cysts at concentrations ranging from $<1$ to 12 cyst/L (Azman et al., 2009; Lim et al., 2009). Low cyst concentrations ( $<1$ cyst/L) were found in samples from recreational waters facilities, such as public swimming pools and water parks, in Italy, the United States, and Belgium (Oliveri et al., 2006; Shield et al., 2008; Ehsan et al., 2015b). The detection of cysts in filter backwash samples of swimming pools in USA and Belgium indicated a need to improve pool operation and maintenance (Shield et al., 2008; Ehsan et al., 2015).

Contamination of natural recreational fresh and marine waters is usually due to urban and non-urban runoff, storm waters, and human or animal wastes. Contamination of swimming pools is typically associated with accidental fecal contamination, particularly from toddlers in wading pools, but can also be caused by poorly constructed and/or maintained plumbing and disinfection processes (Karanis et al., 2006). Molecular analyses have identified Giardia duodenalis Assemblage A in samples from lakes in Malaysia (Lim et al., 2008), and Assemblages AI, AII, BIII and E in samples from lakes in Belgium (Ehsan et al., 2015), again indicating that both human and animal feces contribute to contamination. 


\subsubsection{Ground waters}

A considerable number of people are supplied with ground water (springs, wells, and boreholes). Groundwater is supplied by waterworks or from single-household wells in some communities (Guzman-Herrador et al., 2015). For example, in Europe, ground water contributes to $>99 \%$ of the daily water supply in Denmark, 85\% in Sweden, $41 \%$ in Finland, and 39\% in Norway (Guzman-Herrador et al., 2015). The way this water is provided for human consumption also differs among countries. In the United States, an estimated 114 million people receive their drinking water from public water systems that use a ground water source, whereas approximately 20 million people drink untreated water from public ground water systems (Wallender et al., 2014). In Nordic regions, ground water is usually not disinfected (Guzman-Herrador et al., 2015).

Studies on contamination of ground water with Giardia cysts are scarce; the available data are presented in Table
6. A study in Bulgaria found Giardia cysts in $11 \%$ of water samples from wells and springs, with concentrations ranging from 0.016 to $1.28 \times 10^{2}$ cysts/L (Karanis et al., 2006). In Germany, cysts were detected in only one of 66 wells, with a low level of contamination ( $<0.1$ cyst/L) (Gallas-Lindemann et al., 2013). In Spain, cysts were detected in $44.4 \%$ of boreholes and springs with concentrations ranging from 2 to 12 cysts/L, and were characterized at the molecular level as Assemblages AI and E, suggesting hoofed animals as the main contamination source (Castro-Hermida et al., 2015). Studies in Malaysia and Nepal found cysts in $17.9 \%$ and $22 \%$ of the wells tested, respectively, with higher cyst numbers in Malaysia (1.1 to 2.2 cysts/L) (Lim et al., 2008, Haramoto et al., 2011). Interestingly, a study in an important tourist city in Brazil found Giardia cysts in $25 \%$ of the samples taken from springs that is used for consumption by the local population and tourists, albeit contamination levels were low (0.07 to 0.1 cysts/L) this water is (Branco et al., 2012).

Table 6. Occurrence of Giardia cysts in ground water

\begin{tabular}{|c|c|c|c|c|}
\hline Area & Sample Type & $\begin{array}{l}\text { Percent Positive } \\
\text { (\# of samples) }\end{array}$ & $\begin{array}{c}\text { Concentration Average (range), } \\
\text { Cysts/L }\end{array}$ & Reference \\
\hline Brazil & Springs & $\begin{array}{l}25.0 \% \\
(3 / 12)\end{array}$ & 0.07 to 0.1 & $\begin{array}{l}\text { Branco et al., } \\
2012\end{array}$ \\
\hline Bulgaria & Wells & $\begin{array}{l}11.1 \%^{\mathrm{a}} \\
(2 / 18)\end{array}$ & $1.6 \mathrm{E}-02$ to $1.3 \mathrm{E}+02$ & $\begin{array}{c}\text { Karanis et al., } \\
2006\end{array}$ \\
\hline Germany & $\begin{array}{c}\text { Radial and } \\
\text { vertical wells }\end{array}$ & $\begin{array}{l}1.5 \%{ }^{\mathrm{c}} \\
(1 / 66)\end{array}$ & 0 to 0.5 & $\begin{array}{l}\text { Gallas-Lindemann } \\
\text { et al., } 2013\end{array}$ \\
\hline Malaysia & Wells & $\begin{array}{l}17.9 \% \\
(6 / 28)\end{array}$ & 0 to 0.25 & Lim et al., 2008 \\
\hline Nepal & Shallow wells & $\begin{array}{c}22.0 \%{ }^{\mathrm{b}} \\
(2 / 9)\end{array}$ & 1.1 to 2.2 & $\begin{array}{l}\text { Haramoto et al., } \\
2012\end{array}$ \\
\hline Spain & Boreholes & $\begin{array}{l}44.4 \%^{\mathrm{b}, \mathrm{d}} \\
(12 / 27)\end{array}$ & 2 to 12 & $\begin{array}{l}\text { Castro-Hermida } \\
\text { et al., } 2015\end{array}$ \\
\hline
\end{tabular}

${ }^{\mathrm{a}}$ IFA, ${ }^{\mathrm{b}}$ IMS-IFA, c sucrose centrifugation and IFA

${ }^{\mathrm{d}}$ G. duodenalis Assemblages found A (AI) and E

Groundwater can pose a significant human health risk, particularly if acquired from poorly constructed or maintained wells, close proximity to a contaminant source, such as septic system or surface water source, contamination by animal feces or manure piles, or if locationed at vulnerable hydrogeological formations (Wallender et al., 2014; Painter et al, 2015). Recently a review of all drinking water outbreaks associated to untreated groundwater that occurred in the United States during 1971 to 2008 revealed that among the 172 outbreaks with contributing factor data available, the leading contamination sources included human sewage (33.1\%), animal contamination (9.3\%), and contamination entering via the distribution system $(7.0 \%)$ (Wallender et al., 2014).

\subsubsection{Drinking waters}

Cysts have been detected in final treated drinking water from water works in different countries (Table 7). In general, surveys have reported prevalence rates between 6.5 and $46 \%$ and concentrations typically lesser than one cyst /L. However, higher concentrations were noticed in surveys carried out in Galicia, Spain (Castro-Hermida et al., 2008; 2010; 2015). In these surveys, cysts were detected both in conventional treatment plants and in small treatment facilities, at levels ranging from 0.5 to 18 cysts/L and mean concentrations of $0.5-4.0$ cysts/L (CastroHermida et al., 2008), 1.0-1.5 cysts/L (Castro-Hermida et al., 2010) and 2.8-3.3 cysts/L (Castro-Hermida et al., 2015). The presence of high numbers of cysts in the final treated 
water implies that the treatment processes applied are not fully effective (Castro-Hermida et al., 2015). In addition, genotyping analysis of the isolates revealed the presence of
Assemblages A (AI and AII) and E in final treated water, suggesting contamination by human and hoofed animals (Castro-Hermida et al., 2008; 2015).

Table 7. Occurrence of Giardia cysts in treated drinking water

\begin{tabular}{|c|c|c|c|c|}
\hline Area & Sample Type & $\begin{array}{l}\text { Percent Positive } \\
\text { (\# of Samples) }\end{array}$ & $\begin{array}{c}\text { Concentration Average (range), } \\
\text { Cysts/L }\end{array}$ & Reference \\
\hline Australia & $\begin{array}{l}\text { Tap water } \\
\text { from } \\
\text { rainwater } \\
\text { tanks }\end{array}$ & $\begin{array}{l}12.5 \%^{\mathrm{a}} \\
(3 / 24)\end{array}$ & 110 to 140 & $\begin{array}{c}\text { Ahmed et al., } \\
2012\end{array}$ \\
\hline Brazil & $\begin{array}{c}\text { Finished } \\
\text { water at a } \\
\text { treatment } \\
\text { plant }\end{array}$ & $\begin{array}{l}41.7 \%^{\mathrm{b}} \\
(5 / 12)\end{array}$ & 0 to 0.06 & $\begin{array}{l}\text { Razzolini et al., } \\
2010\end{array}$ \\
\hline Bulgaria & Tap water & $\begin{array}{l}6.5 \%{ }^{\mathrm{c}} \\
(3 / 46)\end{array}$ & $4.0 \mathrm{E}-3$ to 0.5 & $\begin{array}{l}\text { Karanis et al., } \\
2006\end{array}$ \\
\hline Hungary & $\begin{array}{l}\text { Final water } \\
\text { from } \\
\text { treatment } \\
\text { plants }\end{array}$ & $\begin{array}{l}26.7 \%^{\mathrm{b}} \\
(12 / 45)\end{array}$ & 0.63 (Max) & $\begin{array}{l}\text { Plutzer et al., } \\
2007\end{array}$ \\
\hline Japan & $\begin{array}{c}\text { Filtered } \\
\text { water at } \\
\text { treatment } \\
\text { plant }\end{array}$ & $\begin{array}{l}12.0 \% \\
(3 / 26)\end{array}$ & $5.0 \mathrm{E}-04$ to $2.0 \mathrm{E}-03$ & $\begin{array}{l}\text { Hashimoto et } \\
\text { al., } 2001\end{array}$ \\
\hline Portugal & $\begin{array}{c}\text { Treated } \\
\text { water at } \\
\text { treatment } \\
\text { plants }\end{array}$ & $\begin{array}{l}25.6 \%^{\mathrm{b}, \mathrm{d}} \\
(27 / 106)\end{array}$ & NR & $\begin{array}{l}\text { Lobo et al., } \\
2009\end{array}$ \\
\hline Portugal & $\begin{array}{l}\text { Water from } \\
\text { treatment } \\
\text { plants }\end{array}$ & $\begin{array}{l}15.5 \%{ }^{\mathrm{b}, \mathrm{e}} \\
(26 / 167)\end{array}$ & 0.01 to 10.8 & $\begin{array}{c}\text { Almeida et al., } \\
2010\end{array}$ \\
\hline Russia & $\begin{array}{c}\text { Water } \\
\text { treatment } \\
\text { plant }\end{array}$ & $\begin{array}{l}7.1 \%{ }^{b} \\
(5 / 70)\end{array}$ & $1.6 \mathrm{E}-04$ & $\begin{array}{l}\text { Egorov et al., } \\
2002\end{array}$ \\
\hline Spain & $\begin{array}{c}\text { Treated } \\
\text { water from } \\
\text { facilities }\end{array}$ & $\begin{array}{l}19.2 \%{ }^{b} \\
(5 / 26)\end{array}$ & 0 to 0.25 & $\begin{array}{c}\text { Carmena et al., } \\
2007\end{array}$ \\
\hline Spain & Tap water & $\begin{array}{l}26.8 \%^{b} \\
(22 / 82)\end{array}$ & 0 to 0.62 & $\begin{array}{c}\text { Carmena et al., } \\
2007\end{array}$ \\
\hline Spain & $\begin{array}{c}\text { Final treated } \\
\text { effluent } \\
\text { water }\end{array}$ & $\begin{array}{c}100.0 \% \text { b,f } \\
(16 / 16)\end{array}$ & 0.5 to 4 & $\begin{array}{c}\text { Castro-Hermida } \\
\text { et al., } 2008\end{array}$ \\
\hline Spain & $\begin{array}{c}\text { Treated } \\
\text { water at } \\
\text { treatment } \\
\text { plant }\end{array}$ & $\begin{array}{l}36.5 \%{ }^{b} \\
(19 / 52)\end{array}$ & 1 to 5 & $\begin{array}{c}\text { Castro-Hermida } \\
\text { et al., } 2010\end{array}$ \\
\hline Spain & $\begin{array}{l}\text { Treated } \\
\text { water from } \\
\text { treatment } \\
\text { plants }\end{array}$ & $\begin{array}{l}45.7 \%^{\mathrm{b}, \mathrm{f}} \\
(58 / 127)\end{array}$ & 1 to 18 & $\begin{array}{l}\text { Castro-Hermida } \\
\text { et al., } 2015\end{array}$ \\
\hline Venezuela & $\begin{array}{c}\text { Finished } \\
\text { water at } \\
\text { treatment } \\
\text { plants }\end{array}$ & $\begin{array}{c}33.3 \%^{\mathrm{b}} \\
(5 / 15)\end{array}$ & 0.05 to 0.25 & $\begin{array}{l}\text { Betancourt et } \\
\text { al, } 2012\end{array}$ \\
\hline \multicolumn{5}{|c|}{ NR - Not Reported } \\
\hline \multicolumn{5}{|c|}{${ }^{\mathrm{a}} \mathrm{qPCR},{ }^{\mathrm{b}} \mathrm{IMS}-\mathrm{IFA},{ }^{\mathrm{c}}$ filtration, flocculation, sucrose gradient and IFA } \\
\hline \multicolumn{5}{|c|}{ G. duodenalis Assemblages ${ }^{\mathrm{d}}$ Assemblage A (AI), ${ }^{\mathrm{e}}$ Assemblages A (AII), B and E, ${ }^{\mathrm{f}}$ Assemblages A (AI, AII) and E } \\
\hline
\end{tabular}


Very occasionally, Giardia cysts have been detected in tap water samples (Karanis et al., 2006; Bajer et al., 2012). In Bulgaria, cysts were found in $6.5 \%$ of samples, with concentration ranging from 0.004 to 0.5 cysts/L (Karanis et al., 2006).

\subsubsection{Rainwater harvesting}

In areas where potable water is scarce, communities are looking for alternative sources of water supply, such as rainwater collected from roofs in residential dwellings. A recent study of a sustainable community located in Australia, found that, among 24 households, $12.5 \%$ of water samples from rainwater tanks and connected household taps contained Giardia cysts at levels ranging from $1.1 \times 10^{2}$ to $5.8 \times 10^{2}$ cysts/L and from $1.1 \times 10^{2}$ to $1.4 \times 10^{2}$ cysts/L, respectively (Ahmed et al., 2012). Wild animals, such as birds, mammals, and reptiles, that have access to roofs, are the most likely sources of rainwater contamination. Since all households use captured rainwater as drinking water, residents can be at risk of infection.

\subsubsection{Seawater and shellfish}

Increased population density in coastal communities is contributing to seawater quality degradation, especially through sewage discharges and agricultural runoff. Studies on fecal contamination of coastal and estuarine waters with domestic sewage have highlighted the risk associated with exposure to various pathogens.

The occurrence of Giardia cysts has been reported in coastal and estuarine waters (Table 8). In the United States, Giardia cysts were found in $20 \%$ of water samples assessed, with concentrations ranging from 0 to 33 cysts/L (Graczyk et al., 2007b). Interestingly, a positive correlation between the number of bathers and the number of cysts in water was observed; indeed, samples collected during weekend days showed higher concentrations (mean, 9.1 cysts/L) than those collected on weekdays (mean, 0.6 cysts/L). Most probably, the higher number of bathers during weekends contributed to an increase in cysts via resuspension of bottom sediments and direct input (Graczyk et al., 2007b). More recently, Giardia cysts were detected in seawater samples from a shoreline region of Gaza City (Hilles et al., 2014). In this overpopulated area, the lack of appropriate wastewater treatment facilities leads to a huge discharge of untreated or only partially treated sewage directly into the seashore (Hilles et al., 2014).

Table 8. Occurrence of Giardia cysts in seawater

\begin{tabular}{|c|c|c|c|c|}
\hline Area & $\begin{array}{l}\text { Sample } \\
\text { Type } \\
\end{array}$ & $\begin{array}{l}\text { Percent Positive } \\
\text { (\# of samples) } \\
\end{array}$ & $\begin{array}{c}\text { Concentration Average (range), } \\
\text { Cysts/L }\end{array}$ & Reference \\
\hline Brazil & Estuarine & $\begin{array}{c}25.0 \%^{\mathrm{a}} \\
(1 / 4)\end{array}$ & NR & $\begin{array}{l}\text { Souza et al., } \\
2012\end{array}$ \\
\hline $\begin{array}{l}\text { Gaza } \\
\text { Strip }\end{array}$ & $\begin{array}{l}\text { Coastal } \\
\text { water }\end{array}$ & $\begin{array}{l}2.3 \%{ }^{\mathrm{c}} \\
(1 / 52)\end{array}$ & NR & $\begin{array}{l}\text { Hilles et al., } \\
\quad 2014\end{array}$ \\
\hline Mexico & Beaches & $\begin{array}{l}65.6 \%{ }^{a, d} \\
(21 / 32)\end{array}$ & 1 to 30 & $\begin{array}{l}\text { Magana-Odorica } \\
\text { et al., } 2010\end{array}$ \\
\hline USA & Beaches & $\begin{array}{l}20.0 \%{ }^{b} \\
(12 / 60)\end{array}$ & 4 to 33 & $\begin{array}{l}\text { Graczyk et al., } \\
2007\end{array}$ \\
\hline Venezuela & Beaches & $\begin{array}{l}35.0 \%^{\mathrm{a}} \\
(9 / 26)\end{array}$ & 0.2 to 17 & $\begin{array}{l}\text { Betancourt et } \\
\text { al., } 2014\end{array}$ \\
\hline
\end{tabular}

\author{
NR - Not Reported \\ ${ }^{\mathrm{a}}$ IMS-IFA, ${ }^{\mathrm{b}}$ flotation and Fish, ${ }^{\mathrm{c}}$ microscopy \\ ${ }^{\mathrm{d}}$ Assemblage A
}

Surveys have also focused on tropical beach areas, which are visited year-round by many tourists. In Mexico, cysts were found in $65 \%$ of marine recreational water samples, with a concentration ranging from 1 to 30 cysts/L (Magana-Odorica et al., 2010). In Venezuelan marine beaches, cysts were detected in $85 \%$ of water samples collected in near-shore swimming areas at concentrations ranging from <0.2 to 17 cysts/L (Betancourt et al., 2014). While no outbreaks of giardiasis were linked to exposure to contaminated seawater, occurrence of Giardia cysts nevertheless suggests a notable risk to marine bathing waters.

Worldwide, consumption of seafood has increased in the 
context of a healthy and sustainable lifestyle; however, marine water pollution raises safety issues. This is particularly the case for bivalve shellfish (oysters, clams, mussels) that are consumed raw or undercooked, and that are capable of accumulating waterborne pathogens by filter feeding. Moreover, some practices in aquaculture, particularly in use in developing countries, involve the direct addition of untreated or partially treated waste and contaminated surface waters as nutrient sources (WHO, 2006).

Giardia cysts have been recovered from clams, mussels and oysters harvested in different regions of the world
(Table 9). In Spain, cysts were found in $42 \%$ of mussels from shellfish harvesting areas along the Galician coast, with concentrations ranging from 1 to 19 cysts/40 $\mu \mathrm{l}$ of tissue (Gómez-Couso et al., 2005). In the Netherlands, cysts have been isolated from both commercial and noncommercial oysters with an overall prevalence of $3.4 \%$, as well as from sewage effluents that can reach the oysterharvesting sites in the sea (Schets et al., 2007). In Ireland, wild mussels species from twelve sites in surface inland and coastal waters were examined, and cysts were found at eleven $(92 \%)$ of these sites, including sites receiving effluents discharges from wastewater treatment plants and used for leisure (Lucy et al., 2008).

Table 9. Occurrence of Giardia cysts in fish and shellfish

\begin{tabular}{|c|c|c|c|c|}
\hline Area & Sample Type & $\begin{array}{l}\text { Percent } \\
\text { positive } \\
\text { (\# of } \\
\text { samples) }\end{array}$ & $\begin{array}{c}\text { Concentration Average (range), } \\
\text { Cysts/L }\end{array}$ & Reference \\
\hline Australia & $\begin{array}{c}\text { Marine and } \\
\text { freshwater shellfishes } \\
\text { and finger lings }\end{array}$ & $\begin{array}{c}3.8 \% \%^{\mathrm{g}, \mathrm{i}} \\
(27 / 709)\end{array}$ & NR & Yang et al., 2010 \\
\hline Egypt & Fish & $\begin{array}{l}3.3 \%{ }^{\mathrm{b}, \mathrm{f}} \\
(3 / 92)\end{array}$ & NR & $\begin{array}{l}\text { Ghoneim et al., } \\
\qquad 2012\end{array}$ \\
\hline Ireland & Mussels & $\begin{array}{l}91.7 \%^{\mathrm{a}, \mathrm{c}} \\
(11 / 12)\end{array}$ & 1 to 13 & Lucy et al., 2008 \\
\hline Italy & Mussels & $\begin{array}{c}10.0 \%{ }^{\mathrm{g}, \mathrm{h}} \\
(6 / 60)\end{array}$ & NR & $\begin{array}{l}\text { Giangaspero et al., } \\
2014\end{array}$ \\
\hline Netherlands & $\begin{array}{l}\text { Oysters (non- } \\
\text { commercial) }\end{array}$ & $\begin{array}{l}6.7 \%^{\mathrm{a}} \\
(9 / 133)\end{array}$ & NR & Schets et al., 2007 \\
\hline Netherlands & Oysters (Commercial) & $\begin{array}{c}13.0 \%^{\mathrm{a}} \\
(6 / 46)\end{array}$ & NR & Schets et al., 2007 \\
\hline Spain & Mussels & $\begin{array}{c}41.8 \%{ }^{\mathrm{a}} \\
(77 / 184)\end{array}$ & 1 to 19 & $\begin{array}{l}\text { Gòmez-Couso et } \\
\text { al., } 2005\end{array}$ \\
\hline USA & Mussels & $\begin{array}{l}0.4 \% \%^{\mathrm{e}, \mathrm{b}, \mathrm{j}} \\
(4 / 961)\end{array}$ & NR & Adell et al., 2014 \\
\hline
\end{tabular}

\author{
NR - Not Reported \\ ${ }^{\mathrm{a}}$ IFA, ${ }^{\mathrm{b}} \mathrm{PCR},{ }^{\mathrm{c}}$ Fish, ${ }^{\mathrm{d}}$ Sucrose flotation, ${ }^{\mathrm{e}}$ IMS-IFA, ${ }^{\mathrm{f}}$ ELISA, ${ }^{g}$ PCR and sequencing \\ G. duodenalis ${ }^{\mathrm{h}}$ Assemblage A, ${ }^{\mathrm{i}}$ Assemblages A, B and E, ${ }^{\mathrm{j}}$ Assemblages B, C and D
}

To date, in the few reports that investigated species and genotypes of Giardia in molluscan shellfish, the zoonotic Assemblages A and B, and the non-zoonotic Assemblages C, $\mathrm{D}$ and $\mathrm{E}$ were identified (Table 9). Recently, Assemblage A was detected in 23.3\% (14/60) of the Mediterranean mussels (Mytilus galloprovincialis) purchased from markets in the city of Foggia, Italy (Giangaspero et al., 2014). In the United States, Assemblages B, C and D were detected in the hemolymph from mussels collected in Californian coastal areas near possible sources of pathogen pollution, adjacent to freshwater sources (Adell et al., 2014). Despite the proven occurrence of cysts in shellfish, there are no reported outbreaks of giardiasis due to the consumption of oysters, clams or mussels (Willis et al., 2013). This may be due to the strong underestimation of foodborne outbreaks of giardiasis.

Investigations for the presence of Giardia have been carried out also on fish (Table 9). In Australia, cultured fingerlings, wild freshwater and marine/estuarine fishes were tested for the presence of Giardia (Yang et al., 2010). Twenty-seven of the 709 fishes (3.8\%) analyzed were positive by PCR, but the hatchery reared fingerlings had the highest prevalence (19/227, 8.4\%). The genetic analysis revealed G. duodenalis Assemblages A, B and E, but also Giardia microti, a species infecting rodents (e.g., voles and muskrats). In a recent study in Egypt, G. duodenalis was detected in $3.4 \%$ of fecal samples from both farmed and 
wild fish in the Nile River, and all isolates were genotyped as Assemblage A (Ghoneim et al., 2012).

\subsection{Persistence}

Despite many reports on the occurrence of Giardia in the environment, little is known about the actual viability of cysts and the potential to cause infection. The methods commonly applied for the detection of cysts in environmental samples do not differentiate between viable and nonviable organisms. Thus, one of the ongoing challenges is that the assessments of cyst survival require estimates of cyst viability. Procedures to evaluate viability include morphological criteria, inclusion/exclusion of fluorogenic vital dyes, such as 4', 6'- diamidino-2phenyiindole (DAPI) and propidium iodide (PI), propidium monoazide (PMA), fluorescent in situ hibridisation (FISH), in vitro excystation, animal infectivity assays, and nucleic acid-base assays (Health Canada, 2012). The inclusion or exclusion vital dyes have been used extensively to assess viability; however, these methods are not sufficient to determine if cysts are infectious.

Cysts remain viable outside the host for extended periods of time depending on environmental factors such as temperature and relative humidity, but also some physical, chemical and biological characteristics of matrices $(\mathrm{pH}$, dissolved oxygen, turbidity, etc). Temperature is considered the most important factor influencing the survival of cysts, but they are also susceptible to desiccation and direct sunlight, which are able to affect the persistence with a fast die-off of cysts (Percival et al., 2004; Alum et al., 2014).

Survival in water ranges from weeks to months, and it is primarily dependent on decreased environment temperature (USEPA, 1999). However, the occurrence of freeze-thaw cycles may be a relevant contributor to the decline in cyst viability (Robertson and Gjerde, 2006). Bingham et al. (1979) observed that Giardiacysts can survive for up to 77 days in tap water at $8^{\circ} \mathrm{C}$, compared with 4 days at $37^{\circ} \mathrm{C}$. A laboratory study using PI dye exclusion and mouse infectivity assays demonstrated that temperatures as low as $-4^{\circ} \mathrm{C}$ are able to inactivate Giardia cysts in water, while infectivity is maintained for 11 weeks at $4^{\circ} \mathrm{C}$ (Olson et al., 1999). The viability of Giardia cysts (Giardia muris is used as a model) was assessed in lake, river, and tap water (de Regnier et al., 1989). By using PI dye exclusion and in vivo assay, this study found that cysts suspended at $30 \mathrm{ft}$ in lake water remained viable for up to 56 days, whereas cysts stored at $15 \mathrm{ft}$ were nonviable after day 28. Cysts exposed to river water remained viable up to 28 days as determined by in vivo assays. Additionally, cysts exposed to tap water were nonviable by day 14 . In another study, the fate of Giardia cysts was investigated in an aquatic environment in Norway. The study was conducted during the winter season (temperature range, $1-7^{\circ} \mathrm{C}$ ). Morphology and uptake of dyes were used as indicators of viability (Robertson and Gjerde, 2006). The results showed that no apparently viable cysts could be detected after 1 month, suggesting that Giardia cysts cannot survive during the winter.

In addition to the temperature, sunlight can be detrimental to cysts survival in the aquatic environment. Sunlight has germicidal effects as it provides both ultraviolet (UV) radiation and heat, which also depends on the exposure duration and intensity (Mtapuri-Zinyowera et al., 2009). In Zimbabwe, a study to assess the impact of natural sunlight on water contaminated with Giardia cysts and stored in PET (polyethylene terephthalate) containers demonstrated that solar radiation and heat produced by the sun have a synergistic effect in killing cysts when temperatures rise above $50^{\circ} \mathrm{C}$, with complete death at $56^{\circ} \mathrm{C}$ (Mtapuri-Zinyowera et al., 2009).

In drinking water, Giardia cysts can be effectively killed after boiling for one minute.

Information on the survival of Giardiacysts in marine environments is limited and additional research is needed in this area. Survival of cysts in marine waters is important in relation to recreational water activities and through consumption of uncooked oysters, clams, or mussels (Nordic Council of Ministers, 2007). Giardia cysts are sensitive to both salinity and sunlight, and both factors decrease cysts survival time (Johnson et al., 1997). In the dark, cysts can survive up to 77 hours as compared to only 3 hours in the presence of light.

\subsection{Reductions by Sanitation Management}

\subsection{Excreta and Wastewater Treatment}

Wastewater treatment involves a number of types and various sequential steps in some cases, which may include a combination of physical (sedimentation, filtration, solar radiation and UV), biological (activated sludge, organic matter removal) and chemical (coagulation, oxidation) stages. Combination of these processes is meant to create a multi-barrier, present at all times, to minimize the health risk posed by the treated wastewater (Zhang et al., 2012).

\subsubsection{On-Site sanitation}

\subsubsection{Dry onsite sanitation systems}

The association of water, sanitation, and hygiene (WASH) on neglected tropical diseases is attracting interest, and this issue has been recently reviewed, with a focus on protozoa, including Giardia (Speich et al., 2016). In their meta-analysis, Speich et al. (2016) showed that people having access to, or using sanitation facilities, have significantly lower odds of being infected with Giardia (0.64) compared with their counterparts who lack access to, or do not use sanitation facilities. Likewise, lower odds (0.63) were observed among people who treat water before consumption. The fact that people without sanitation are at higher odds of being infected with soil-transmitted helminths compared with those with sanitation has been already discussed (Strunz et al, 2014), and strengthen the concept that improved sanitation facilities and safe water are crucial for combating a large number of infectious diseases. 


\subsubsection{Inactivation by storage}

Cysts are able to survive for about one week in solid cattle faeces (manure), but the survival in slurry is longer. The study by Grit et al (2012) investigated the infectivity of Giardia cysts from slurry in two animal models (gerbil and lamb) and concluded that storing cattle slurry for 90 days reduced their number and viability by only $0.64 \log _{10}$ and $1.52 \log _{10}$, respectively.

No relevant data were found as per the effect of pit latrines, vault toilets and dry toilets, except for the study reported above (Speich et al., 2016).

\subsubsection{Water-based onsite sanitation (septic tanks)}

No relevant data on the use, and effect of, septic tanks were found.

\subsubsection{Waste stabilization ponds}

The performance of a stabilization pond in Morocco, consisting of a series of two circular basins, each of a superficial area of $2500 \mathrm{~m}^{2}$ and a depth of $2.3 \mathrm{~m}$ for the first basin and $1.5 \mathrm{~m}$ for the second, was evaluated (Amahmid et al., 1999). In this study, wastewater samples were collected twice monthly for 24 months. Sampling points included the entrance of the first basin, the exit of the first basin, and the exit of the second basin. Sediments were also sampled monthly for 24 months. Results showed that Giardia cysts were detected in $50 \%$ (24 of 48) wastewater samples, with a geometric average concentration of $2.8 \times 10^{3}$ cysts /L. However, only 2 of the 48 samples $(4.2 \%)$ at the exit of the first basin contained Giardia cysts, with a mean number of 21 cysts /L, and no cysts were detected at the outlet of the second basin. For sediment samples, Giardia cysts were detected in $25 \%$ $(18 / 72)$ of samples at the entrance, with an average of $1.3 \mathrm{x}$ $10^{3}$ per gram dry weight. At the exit of the first basin, $5.6 \%$ (4/72) of samples contained Giardiacysts, whereas no cysts were detected in sediment samples taken at the entrance of the second basin.

A waste stabilization pond formed by two anaerobic ponds, a facultative pond, and a maturation pond was examined in Spain. The system operated with only 6 days of total retention time (Reinoso et al., 2011). All raw wastewater samples (10 liters) were positive, with a mean concentration of 67 cysts/L (range 17.2 to $2.17 \times 10^{2}$ cysts/L). The study showed that anaerobic ponds were the most effective in removing parasites followed by the facultative pond and the maturation pond. The removal efficiency was higher during summer (4.3 $\log _{10}$ cysts removed $\mathrm{m}^{-2}$ day $\left.^{-1}\right)$ than in winter $\left(3.9 \log _{10}\right.$ cysts removed $\mathrm{m}^{-2}$ day $\left.^{-1}\right)$. The authors further commented that predation and natural mortality are important in the removal of Giardia cysts.

Four waste stabilization pond systems, two located in subtropical South East Queensland, Australia, serving a population around 1500 inhabitants, and two in wet-dry tropic regions of the Northern Territory, serving 1000-2500 inhabitants, were compared (Sheludchenko et al 2016).
Three of the four systems used baffles. Water samples from the inlet and the outlet of three ponds were tested for the presence of Giardia using the USEPA 1623 method. Highest removal rates were observed in the two WSP which used baffles (2.2 and $1.6 \log _{10}$ ), compared to the one that did not $\left(1.3 \log _{10}\right)$. This result indicates that retention time was a key factor in Giardia cyst removal.

\subsubsection{Aerated lagoons}

A single study compared the removal efficiency of two sewage treatment plants in Malaysia, one using extended aeration (EA, plant A) and the other using an aerated lagoon (AL, plant B) (Lim et al, 2007). Samples of 10 liters from the influent and the treated water were concentrated by sucrose flotation and Giardia cysts detected microscopically after staining with fluorophore conjugated monoclonal antibodies. All water samples (raw and treated) at both plants were positive for Giardia. At plant A, the number of cyst /L ranged from 18 to $5.24 \times 10^{3}$ in raw influent samples and from 1 to $5.0 \times 10^{2}$ in treated sewage effluents. At plant B, the number of cyst /L ranged from 55 to $8.48 \times 10^{3}$ in raw influent samples and from 28 to $1.46 \times 10^{3}$ in treated sewage effluents. Thus, removal rates were $>1$ $\log _{10}$ in both plants, but were higher in plant A $\left(1.4 \log _{10}\right)$ compared to plant B $\left(1.1 \log _{10}\right)$. This is due to the fact that in EA plants, fine bubbles, generated by submerged diffusers, can promote higher oxygen transfer efficiency compared to AL plants, which use surface aerators to provide air [45].

\subsubsection{Constructed wetlands}

Wetlands may provide an attractive low technology and low energy solutions for treating wastewater. Postulated removal mechanisms are settling and sorption of protozoa to wetland vegetation and substrate. Constructed wetlands (or planted soil filters) may be installed either as vertical or as horizontal flow filter constructions. Horizontal systems are further classified, depending on the pathway of water flow, as surface and subsurface flow systems. Removal of Giardia (and other pathogens) by the use of wetlands is influenced by many factors, including vegetation cover, turbidity, salinity, and temperature of the water, as well as disinfection from ultraviolet and solar radiation, and predation from filter feeding and grazing organisms, such as zoo-plankton and snails.

The removal of Giardia cysts at two plants in Germany that received municipal wastewater (population served, 100.000 at Plant A, and 300 at Plant B) was also evaluated (Redder et al., 2010). Samples of wastewater (influents) and effluents (first and second filter flow, and from a facultative pond) were tested by the USEPA 1623 method. The mean concentration of Giardia cysts in the influents was close to 150 cysts $/ 100 \mathrm{~L}$ at both Plants, and a 2 to 3 $\log _{10}$ reduction was observed. The authors commented that the use of a two-stage system consisting of a subsurface horizontal flow filter was essential to achieve an efficient removal of cysts.

Another study by Graczyk and colleagues (Graczyk et 
al., 2009) examined four horizontal wetlands that received unchlorinated municipal wastewater subjected to secondary treatment after sewage sludge activation and secondary sedimentation. Plant A had two components: the first component (surface flow, SF) discharged to the second component (subsurface flow, SSF), with a final effluent released into the groundwater. Plants B, C and D were small-scale surface flow wetlands discharging to surface waters. Grab samples (2 liters) of influents and effluents were processed and Giardia cysts were detected by FISH and IFA. Concentrations of cysts in influents ranged from 8 to 241 cysts/L (mean, $69 \pm 37.7$ ), and from 11 to 140 cysts/L (mean, $88 \pm 24.0$ ) in effluents. Only Plant A achieved a significant removal efficiency $\left(1.3 \log _{10}\right)$, while the number of cysts was higher in the effluents than in influents at the other three Plants. This was interpreted as the result of active deposition of cysts by wild animals.

The efficiency of a combined constructed wetland (facultative pond, FP, SF wetland and SSF wetland) that received domestic raw wastewater from a village (150 habitants) in the province of León, Spain was evaluated (Reinoso et al., 2008). Ten liter samples were collected monthly over a period of 1 year, and cysts were quantified by IFA. The arithmetic mean of Giardia cysts in the influent was 280.94 (SD, 99.14), while in the final effluent was <1 cyst; therefore the cumulative treatment system removal was $3.04 \log _{10}$. The SSF wetland was significantly more efficient in the removal of cysts than SF and FP; the removal rates in SF wetland were significantly higher $(\mathrm{p}<0.05)$ in summer than in winter.
3.1.4 Combined sewer overflows - treatment of fecallypolluted stormwater

Combined sewer overflows (CSOs) occur in combined sewer systems when sewage and stormwater runoff are released into water bodies, potentially contaminating water sources. The use of CSO is necessary to accommodate hydraulic strain when the combined rain and sanitary flows exceed the system capacity. In recent years, the USEPA has identified CSOs as a significant source of pathogens and other pollutants and contaminants in surface water bodies.

A study of the Chicago Area Waterway System (CAWS) assessed the impact of CSO on the microbial quality of the CAWS (Rijal et al., 2011). Dry and wet weather samples were collected upstream and downstream of the three water reclamation plants. During dry weather events, cysts were detected in 32, 68 and $72 \%$ of samples taken from the plants. The concentration of cysts was usually low $(<10$ cysts/L), with the exception of one downstream sample (49.5 cysts/L); the detection of cysts in upstream samples (at concentrations of 0.1 to 5.4 cysts/L) suggests input of cysts in the CAWS from both WRP and non-WRP sources.

\subsubsection{Wastewater Treatment and Resource Recovery Facilities}

Table 10 presents a summary of results from studies conducted at different wastewater treatment plants. The following sections focus on the most relevant treatments and their efficacies in removal of Giardia cysts.

Table 10. A summary of studies on the removal efficiency of Giardia cysts in differently operated wastewater treatment plants

\begin{tabular}{|c|c|c|c|c|c|c|c|c|c|c|}
\hline Area & Plant & $\begin{array}{l}\text { Population } \\
\text { served }\end{array}$ & $\begin{array}{c}\text { Primary } \\
\text { treatment }\end{array}$ & $\begin{array}{l}\text { Secondary } \\
\text { treatment }\end{array}$ & $\begin{array}{c}\text { Tertiary } \\
\text { treatment }\end{array}$ & Disinfection & $\begin{array}{c}\text { Cyst/L } \\
\text { influent } \\
\text { Average } \\
\end{array}$ & $\begin{array}{c}\text { Cyst/L } \\
\text { effluent } \\
\text { Average }\end{array}$ & $\underset{\log 10}{\text { reduction }}$ & Reference \\
\hline Brazil & $\begin{array}{c}\text { Plant } \\
1\end{array}$ & NR & $\begin{array}{l}\text { Screening, } \\
\text { aeration }\end{array}$ & $\begin{array}{l}\text { Activated sludge, } \\
\text { secondary } \\
\text { clarification }\end{array}$ & None & UV & $\begin{array}{c}1 \mathrm{E}+05 \\
\pm 8.7\end{array}$ & $\begin{array}{l}1.1 \mathrm{E}+03 \\
\pm 1.0\end{array}$ & 1.96 & Neto et al 2006 \\
\hline Brazil & $\begin{array}{c}\text { Plant } \\
1\end{array}$ & NR & NR & Activated sludge & $\begin{array}{l}\text { Sand } \\
\text { filtration, } \\
\text { membrane } \\
\text { filtration }\end{array}$ & Chlorine & $2.8 \mathrm{E}+03$ & 18 & 2.19 & $\begin{array}{l}\text { Hachich et al., } \\
2013\end{array}$ \\
\hline Brazil & $\begin{array}{c}\text { Plant } \\
2\end{array}$ & NR & NR & $\begin{array}{l}\text { Upflow anaerobic } \\
\text { sludge blanket, } \\
\text { membrane bioreactor }\end{array}$ & $\begin{array}{c}\text { Ferric } \\
\text { chloride } \\
\text { coagulation, } \\
\text { sedimentation }\end{array}$ & Chlorine & $1.1 \mathrm{E}+03$ & 6 & 2.26 & $\begin{array}{l}\text { Hachich et al., } \\
2013\end{array}$ \\
\hline Brazil & $\begin{array}{c}\text { Plant } \\
3\end{array}$ & NR & NR & Activated sludge & $\begin{array}{l}\text { Sand } \\
\text { filtration }\end{array}$ & Chlorine & $3.9 E+03$ & 3 & 3.11 & $\begin{array}{l}\text { Hachich et al., } \\
2013\end{array}$ \\
\hline Brazil & $\begin{array}{c}\text { Plant } \\
4\end{array}$ & NR & NR & $\begin{array}{l}\text { Anaerobic and } \\
\text { facultative pond }\end{array}$ & $\begin{array}{l}\text { Maturation } \\
\text { pond, } \\
\text { trickling filter }\end{array}$ & None & $9.3 \mathrm{E}+03$ & $<1$ & $>3.97$ & $\begin{array}{l}\text { Hachich et al., } \\
2013\end{array}$ \\
\hline China & WTP-G & NR & $\begin{array}{l}\text { Screening } \\
\text { and grit } \\
\text { removal }\end{array}$ & Activated sludge & $\begin{array}{l}\text { Sand } \\
\text { filtration }\end{array}$ & None & $1.6 \mathrm{E}+03$ & 0.53 & 3.02 & Fu et al 2010 \\
\hline China & WTP-Q & NR & $\begin{array}{l}\text { Screening } \\
\text { and grit } \\
\text { removal }\end{array}$ & $\begin{array}{c}\text { Anaerobic-anoxic-oxic } \\
\text { process }\end{array}$ & $\begin{array}{l}\text { Membrane } \\
\text { ultrafiltration }\end{array}$ & Ozone/chlorine & $9.1 \mathrm{E}+02$ & $<0.033$ & $>2.94$ & Fu et al 2010 \\
\hline China & WTP-J & NR & $\begin{array}{l}\text { Screening } \\
\text { and grit } \\
\text { removal }\end{array}$ & $\begin{array}{l}\text { Oxidation ditch } \\
\text { process }\end{array}$ & None & None & $8.0 \mathrm{E}+02$ & 2 & 2.60 & Fu et al 2010 \\
\hline Germany & $\begin{array}{c}\text { Plant } \\
1\end{array}$ & $5.0 \mathrm{E}+04$ & $\begin{array}{c}\text { Rake, grit } \\
\text { chamber, } \\
\text { sedimentation }\end{array}$ & Activated sludge & $\begin{array}{c}\text { Sand } \\
\text { filtration }\end{array}$ & None & $3.73 E+02$ & 0.51 & 2.39 & $\begin{array}{c}\text { Kistemann et al } \\
2008\end{array}$ \\
\hline
\end{tabular}




\begin{tabular}{|c|c|c|c|c|c|c|c|c|c|c|}
\hline Area & Plant & $\begin{array}{c}\text { Population } \\
\text { served }\end{array}$ & $\begin{array}{c}\text { Primary } \\
\text { treatment }\end{array}$ & $\begin{array}{l}\text { Secondary } \\
\text { treatment }\end{array}$ & $\begin{array}{c}\text { Tertiary } \\
\text { treatment }\end{array}$ & Disinfection & $\begin{array}{c}\text { Cyst/L } \\
\text { influent } \\
\text { Average } \\
\end{array}$ & $\begin{array}{c}\text { Cyst/L } \\
\text { effluent } \\
\text { Average } \\
\end{array}$ & $\begin{array}{c}\log 10 \\
\text { reduction } \\
\end{array}$ & Reference \\
\hline Germany & $\begin{array}{c}\text { Plant } \\
2\end{array}$ & $2.7 \mathrm{E}+04$ & $\begin{array}{c}\text { Rake, grit } \\
\text { chamber, } \\
\text { sedimentation }\end{array}$ & Activated sludge & $\begin{array}{l}\text { Sand } \\
\text { filtration }\end{array}$ & None & $2.12 E+02$ & 0.22 & 2.24 & $\begin{array}{l}\text { Kistemann et al } \\
2008\end{array}$ \\
\hline Germany & $\begin{array}{c}\text { Plant } \\
3\end{array}$ & $1.1 \mathrm{E}+04$ & $\begin{array}{c}\text { Rake, grit } \\
\text { chamber, } \\
\text { sedimentation }\end{array}$ & $\begin{array}{l}\text { Activated sludge, } \\
\text { trickling filter }\end{array}$ & None & None & $2.38 E+02$ & 0.34 & 2.25 & $\begin{array}{l}\text { Kistemann et al } \\
2008\end{array}$ \\
\hline Germany & $\begin{array}{c}\text { Plant } \\
4\end{array}$ & $1.07 \mathrm{E}+04$ & $\begin{array}{c}\text { Rake, grit } \\
\text { chamber, } \\
\text { sedimentation }\end{array}$ & $\begin{array}{l}\text { Activated sludge, } \\
\text { trickling filter }\end{array}$ & None & None & $5.08 \mathrm{E}+02$ & 2.37 & 2.33 & $\begin{array}{l}\text { Kistemann et al } \\
2008\end{array}$ \\
\hline Germany & $\begin{array}{c}\text { Plant } \\
5\end{array}$ & $8 \mathrm{E}+02$ & $\begin{array}{l}\text { Rake, grit } \\
\text { chamber }\end{array}$ & Activated sludge & None & None & $1.61 \mathrm{E}+02$ & 0.21 & 2.12 & $\begin{array}{c}\text { Kistemann et al } \\
2008\end{array}$ \\
\hline Germany & $\begin{array}{c}\text { Plant } \\
6\end{array}$ & $5 \mathrm{E}+02$ & $\begin{array}{l}\text { Rake, grit } \\
\text { chamber }\end{array}$ & Activated sludge & None & None & $2.43 E+02$ & 4.5 & 1.73 & $\begin{array}{c}\text { Kistemann et al } \\
2008\end{array}$ \\
\hline Ireland & $\begin{array}{c}\text { Plant } \\
\text { A }\end{array}$ & $1.9 \mathrm{E}+03$ & $\begin{array}{l}\text { Screening } \\
\text { and grit } \\
\text { separation }\end{array}$ & $\begin{array}{l}\text { Sludge activation in } \\
\text { oxidation ditch }\end{array}$ & None & None & $\begin{array}{l}3.20 \mathrm{E}+02 \\
\quad \pm 22.6\end{array}$ & $1 \pm 1.5$ & 2.51 & Cheng et al 2009 \\
\hline Ireland & $\begin{array}{c}\text { Plant } \\
\text { B }\end{array}$ & $1 \mathrm{E}+03$ & None & $\begin{array}{c}\text { Sludge activation in } \\
\text { extended } \\
\text { aeration tanks }\end{array}$ & None & None & $\begin{array}{l}1.23 \mathrm{E}+02 \\
\pm 9.2\end{array}$ & $3 \pm 1.5$ & 1.61 & Cheng et al 2009 \\
\hline Ireland & $\begin{array}{l}\text { Plant } \\
\text { C }\end{array}$ & $2.5 \mathrm{E}+03$ & $\begin{array}{l}\text { Screening } \\
\text { and grit } \\
\text { separation }\end{array}$ & $\begin{array}{c}\text { Sludge activation in } \\
\text { extended } \\
\text { aeration tanks }\end{array}$ & None & None & $7 \pm 4.1$ & $<1$ & $>0.85$ & Cheng et al 2009 \\
\hline Ireland & $\begin{array}{l}\text { Plant } \\
\text { D }\end{array}$ & $2.1 \mathrm{E}+03$ & $\begin{array}{l}\text { Screening } \\
\text { and grit } \\
\text { separation }\end{array}$ & $\begin{array}{l}\text { Biofilm-coated } \\
\text { percolating filter }\end{array}$ & None & None & NR & $1 \pm 1.1$ & NR & Cheng et al 2009 \\
\hline Italy & $\begin{array}{c}\text { Plant } \\
\text { A }\end{array}$ & $1.5 \mathrm{E}+05$ & $\begin{array}{l}\text { Screening } \\
\text { and grit } \\
\text { separation }\end{array}$ & $\begin{array}{l}\text { Oxidation with } \mathrm{O} 2 \\
\text { and sedimentation }\end{array}$ & None & None & $1.6 \mathrm{E}+05$ & $1.56 \mathrm{E}+02$ & 3.01 & Cacciò et al 2003 \\
\hline Italy & $\begin{array}{c}\text { Plant } \\
\text { B }\end{array}$ & $3.3 \mathrm{E}+05$ & $\begin{array}{c}\text { Screening, } \\
\text { grit } \\
\text { separation } \\
\text { and } \\
\text { sedimentation }\end{array}$ & $\begin{array}{l}\text { Activated sludge and } \\
\text { sedimentation }\end{array}$ & None & Chlorination & $1.16 \mathrm{E}+05$ & $2.8 \mathrm{E}+04$ & 0.62 & Cacciò et al 2003 \\
\hline Italy & $\begin{array}{l}\text { Plant } \\
\text { D }\end{array}$ & $1 E+05$ & $\begin{array}{c}\text { Screening, } \\
\text { grit } \\
\text { separation } \\
\text { and } \\
\text { sedimentation }\end{array}$ & $\begin{array}{l}\text { Activated sludge and } \\
\text { sedimentation }\end{array}$ & None & $\begin{array}{l}\text { Filtration and } \\
\text { peracetic acid }\end{array}$ & $3.61 E+05$ & $2.7 \mathrm{E}+03$ & 2.13 & Cacciò et al 2003 \\
\hline Spain & $\begin{array}{c}\text { Plant } \\
1\end{array}$ & $2.5 \mathrm{E}+05$ & $\begin{array}{c}\text { Screening } \\
\text { and grit } \\
\text { separation, } \\
\text { sedimentation }\end{array}$ & $\begin{array}{l}\text { Anaerobic digestion, } \\
\text { sedimentation }\end{array}$ & None & UV & NR & 0 to 13.2 & 2.33 & $\begin{array}{c}\text { Rodriguez-Manzano } \\
\text { et al, } 2012\end{array}$ \\
\hline Spain & $\begin{array}{c}\text { Plant } \\
2\end{array}$ & $2.5 \mathrm{E}+05$ & $\begin{array}{l}\text { Screening } \\
\text { and grit } \\
\text { separation, } \\
\text { sedimentation }\end{array}$ & $\begin{array}{l}\text { Anaerobic digestion, } \\
\text { sedimentation }\end{array}$ & $\begin{array}{l}\text { Sand } \\
\text { filtration }\end{array}$ & UV & NR & 0.4 to 2 & 2.98 & $\begin{array}{l}\text { [53] Rodriguez- } \\
\text { Manzano et al, } \\
2012\end{array}$ \\
\hline Tunisia & $\begin{array}{c}\text { Plant } \\
1\end{array}$ & $1.9 \mathrm{E}+04$ & $\begin{array}{c}\text { Primary } \\
\text { decantation }\end{array}$ & Oxidation channel & None & None & $3.2 \mathrm{E}+02$ & $<1$ & $>2.51$ & Khouja et al 2010 \\
\hline Tunisia & $\begin{array}{c}\text { Plant } \\
2\end{array}$ & $6.3 E+05$ & $\begin{array}{c}\text { Primary } \\
\text { decantation }\end{array}$ & Oxidation channel & None & None & $2.6 \mathrm{E}+02$ & $<1$ & $>2.41$ & Khouja et al 2010 \\
\hline Tunisia & $\begin{array}{c}\text { Plant } \\
3\end{array}$ & NR & $\begin{array}{c}\text { Primary } \\
\text { decantation }\end{array}$ & Activated sludge & None & UV & $2 E+02$ & $<1$ & $>2.3$ & Khouja et al 2010 \\
\hline Tunisia & $\begin{array}{c}\text { Plant } \\
4\end{array}$ & $9.8 \mathrm{E}+03$ & None & Aerated lagoon & None & None & $1.06 \mathrm{E}+02$ & 2 & 2.02 & Khouja et al 2010 \\
\hline Tunisia & $\begin{array}{l}\text { Plant } \\
5\end{array}$ & $1 E+06$ & $\begin{array}{c}\text { Primary } \\
\text { decantation }\end{array}$ & Oxidation channel & None & None & $1.6 \mathrm{E}+02$ & 2 & 1.9 & Khouja et al 2010 \\
\hline USA & $\begin{array}{c}\text { Plant } \\
\text { A }\end{array}$ & $5.0 \mathrm{E}+05$ & Not indicated & Activated sludge & None & Chlorination & $4.8 \mathrm{E}+03$ & 33 & $2.08 \pm 0.44$ & Kitajima et al 2014 \\
\hline USA & $\begin{array}{c}\text { Plant } \\
\text { B }\end{array}$ & $2.5 \mathrm{E}+05$ & Not indicated & Trickling filter & None & Chlorination & $6.4 \mathrm{E}+03$ & $1.9 \mathrm{E}+02$ & $1.52 \pm 0.62$ & Kitajima et al 2014 \\
\hline USA & $\begin{array}{c}\text { Plant } \\
1\end{array}$ & NR & Not indicated & $\begin{array}{l}\text { Activated sludge, } \\
\text { lime treatment }\end{array}$ & $\begin{array}{c}\text { Sand } \\
\text { filtration, } \\
\text { upflow } \\
\text { carbon } \\
\text { adsorption }\end{array}$ & Chlorination & $4.9 \mathrm{E}+02$ & 1.1 & 2.65 & Rose et al, 2001 \\
\hline
\end{tabular}




\subsubsection{Primary /preliminary treatment}

Pretreatment may include a sand or grit channel or chamber, where the velocity of the incoming sewage is adjusted to allow the settlement of sand, grit, stones, and broken glass trough the process of sedimentation. Removal of these particles is necessary to prevent damage of pumps and other equipment. Primary treatment consists of temporarily holding the sewage in a quiescent basin where heavy solids can settle to the bottom while oil, grease and lighter solids float to the surface. The settled and floating materials are removed and the remaining liquid may be discharged or subjected to secondary treatment.

Enhanced primary includes coagulation and settling as well as disinfection and is often used when secondary treatment is not available. No data are available on removal of cysts by this method.

Enhanced coagulation is a process used to improve removal of disinfection-by-products precursors through modified conventional treatment that includes reduction of $\mathrm{pH}$ to levels of 5-6 and the use of higher doses of coagulants.

Dissolved air flotation (DAF) is a clarification process used to remove particles in membrane plants or in conventional type plants using granular media filtration. DAF allows removal of fragile floc particles found in water treatment via adherence to air bubbles. DAF can achieve 2-3 $\log _{10}$ removals, compared to removals by sedimentation of $2 \log _{10}$ decreasing to $1 \log _{10}$ or less for winter water temperatures (Edzwald, 2010).

\subsubsection{Trickling filters}

The $\log _{10}$ reduction of Giardia cysts was compared at two wastewater treatment plants in Arizona, one that utilized a conventional activated sludge process (A) and the other that utilized a biological trickling filter process (B) (Kitajima et al., 2014). A total of 48 wastewater samples (12 influent and 12 effluent samples from each of the two plants) were collected, and cysts were concentrated using an electronegative filter method followed by IMS. Molecular assays were also employed to genotype cysts. Giardia cysts were detected in all influent samples with mean concentration of $4.8 \times 10^{3}$ cysts/L and $6.4 \times$ $10^{3}$ cysts/L at Plants A and $B$, respectively. Cysts were also detected in all effluent samples, except one, with mean concentration of $3.3 \times 10^{1} \mathrm{cysts} / \mathrm{L}$ and $1.9 \times 10^{2} \mathrm{cysts} / \mathrm{L}$ at Plants A and B, respectively. The concentration of Giardia cysts in effluent at Plant B was significantly higher than Plant A (t-test, $\mathrm{P}=0.0003)$, suggesting that a conventional activated sludge process $\left(2.2 \log _{10}\right.$ removal $)$ is slightly more efficient than a biological trickling filter process $(1.5$ $\log _{10}$ removal) in removing Giardia cysts.

\subsubsection{Activated sludge}

A bench scale activated sludge reactor was used to simulate the performance of the secondary treatment process in the Bolivar WWTP (Adelaide, South Australia). Bolivar utilizes a conventional biological wastewater treatment process, including activated sludge and biological nutrient removal (Wen et al., 2009). The laboratory system was fed with primary settled wastewater from the Bolivar WWTP, and six samples were taken, including three influent and three effluent samples. The number of Giardia cysts in the influent varied from 2.5 to $8.2 \times 10^{3} / \mathrm{L}$, whereas in the effluent the number varied from 1.7 to $8.0 \times 10^{1} / \mathrm{L}$. Therefore, the average $\log _{10}$ reduction was 2.49 (Wen et al, 2009). The removal performance at the Bolivar WWTP was investigated during June and July, and a $\log _{10}$ reduction of 1.42 was estimated, much lower than that in the laboratory system. This difference was attributed to the lower temperature outdoors in winter compared to the constant temperature in the laboratory. Another study in Arizona was mentioned in the previous paragraph (Kitajima et al., 2014).

It is well known that during wastewater treatment, sanitation procedures can result in a significant reduction of Giardia cyst levels. However, information on parasite survival is deficient. In a project undertaken in Nordic countries, FISH was used to estimate cysts viability in raw sewage and in both untreated and treated sludge from treatment plants in Sweden (Nordic Council of Ministers, 2007). Results showed that the viability of cysts entering the sewage treatment varied considerably overtime and before settling into the sludge for further treatments. In two plants from Henriksdals in Stockholm and Tegeludden in Kalmar, viable cysts were detected in untreated sludge samples at every sampling using the FISH assay, with rates of $2.9-41.7 \%$ and $14.3-66.7 \%$, respectively. After sludge treatment by mesophilic and thermophilic digestion, in Henriksdals plant $1.8 \%$ (9/500) cysts were still FISHpositive after mesophilic treatment with a retention time of 21 days. At the Tegeludden plant, 1.2\% (1 of 81) cysts were FISH-positive after thermophilic digestion plus 14 days of retention time. In both anaerobic sanitation procedures, the time/temperature ratio was the key factor affecting cyst viability; however, higher temperatures adopted in thermophilic digestion (around $55^{\circ} \mathrm{C}$ ) resulted in greater reduction of cyst viability (Nordic Council of Ministers, 2007; Dumontet et al., 2001).

\subsubsection{Oxidation ditch}

Giardia cyst removal was compared from three municipal wastewater treatment plants (WWTP) in Beijing, China (Fu et al., 2010). One of the WWTP used an oxidation ditch process as secondary treatment. It was found that oxidation ditch process had higher reduction efficiency for Giardia (2.60 $\log _{10}$ ) than anaerobic-anoxic-oxic process $\left(2.04 \log _{10}\right)$ and conventional activated sludge process (1.68 $\left.\log _{10}\right)$. This was interpreted as the result of longer retention time and higher sludge concentration in these types of treatment processes.

\subsubsection{Membrane bioreactors}

A Membrane BioReactor (MBR) is the combination of a membrane process like microfiltration or ultrafiltration with a suspended growth bioreactor, and is now widely used for municipal and industrial wastewater treatment 
with plant sizes up to 80,000-population equivalent.

The overall water quality produced from 38 satellite MBR facilities located in various parts of the US was evaluated. In the majority of the facilities, submerged MBR configuration, hollow-fiber ultrafiltration membranes and backwashing, as a fouling control strategy, were used (Hirani et al., 2013). Using the USEPA 1623 method, the presence of Giardia cysts was assessed on 10 liter samples of MBR effluent. Only two filtrate samples from two satellite facilities contained cysts (3 cysts/10 liters and 3-18 cysts/10 liters, respectively); it was noted that the two facilities also had much higher particle and bacterial counts than the other satellite plants. However, Giardia cysts are not expected to pass through intact microfiltration or ultrafiltration membranes. Therefore, monitoring of MBR facilities for membrane integrity was suggested.

\subsubsection{Anaerobic/ anoxic digestion and biogas}

The removal efficiency at three WWTP using anaerobic/anoxic digestions were compared. Plant 1 used activated sludge and anaerobic/anoxic/oxic treatment, followed by sand filtration and chlorination, whereas Plant 2 used activated sludge and chlorination, and Plant 3 used trickling filter followed by activated sludge, chlorination and UV (Hatam-Nahavandi et al 2015). Unfortunately, the results were expressed for all protozoan combined. At Plant 1 , the mean concentration of cysts was $1.3 \times 10^{3}\left( \pm 4.1 \times 10^{2}\right)$ / $\mathrm{L}$ in raw water, and $2.5 \times 10^{2}( \pm 59) / \mathrm{L}$ in the treated water $\left(0.72 \log _{10}\right.$ reductions $)$. At Plant 2 , the mean concentration was $1.4 \times 10^{3}\left( \pm 3.8 \times 10^{2}\right) / \mathrm{L}$ in raw water, and $2.4 \times 10^{2}( \pm 89) / \mathrm{L}$ in the treated water $(0.79$ $\log _{10}$ reductions). At Plant 3 , the mean concentration was $1.4 \times 10^{3}\left( \pm 1.4 \times 10^{2}\right) / \mathrm{L}$ in raw water, and $2 \times 10^{2}( \pm 70) / \mathrm{L}$ in the treated water $\left(0.85 \log _{10}\right.$ reductions $)$. Thus, no significant differences in reduction could be attributed to the different treatment processes.

\subsubsection{Coagulation}

The significant role played by chemical lime treatment barrier in the reduction of Giardia was highlighted during an investigation of the Water Reclamation Plant in Virginia (Rose at al,. 2001). This treatment was the most effective along the entire process, achieving a reduction of Giardia cysts by $4.6 \log _{10}$.

\subsubsection{Membranes}

Membrane technologies have a strong potential in the removal of protozoa from wastewater, and ultrafiltration (UF; pore sizes of 0.002 to $0.1 \mu \mathrm{m}$ ) can achieve effective removal of protozoan cysts (4 to $15 \mu \mathrm{m}$ ) by physical sieving. Membrane filtration is also used for clarification and removal of inorganic and synthetic organic chemicals and control of disinfection by-products.

The removal efficiency at a pilot-scale membrane system, where wastewater tertiary treatment was carried out by UF using a submerged hollow-fiber system was investigated (Lonigro et al., 2006). Using direct IF microscopy, Giardia cysts were found in four of four wastewater samples at a concentration of $1.83 \times 10^{3} \pm 1.81$ $\times 10^{3} / \mathrm{L}$ (mean \pm standard deviation). UF resulted in a cyst removal of $3.6 \log _{10}$.

\subsubsection{Sludge management}

The use of lime to reduce or eliminate pathogen content in sewage sludge represents a simple and inexpensive treatment. Lime stabilization is a process where calcium hydroxide $\left(\mathrm{Ca}(\mathrm{OH})_{2}\right)$ or calcium oxide $(\mathrm{CaO})$ is added and the $\mathrm{pH}$ elevated to 12 for 2 or more hours. Giardia cysts, suspended in either water or sludge, and exposed to lime treatments for $24 \mathrm{~h}, 48 \mathrm{~h}$, and $72 \mathrm{~h}$ resulted in cyst inactivation, as demonstrated by lack of infection in experimentally challenged gerbils (Bean et al. 2007).

\subsection{Disinfection}

\subsubsection{Chemical disinfection (chlorine, ozone)}

A study has evaluated the efficiency of ozonation (and UV treatment) in reducing pathogens, including Giardia, in combined sewer overflows (Tondera et al., 2016). Artificial combined wastewater samples were prepared by pumping from the wastewater-settling tank through the pilot testing systems. In the ozone reactor, two doses of ozonation (10 $\mathrm{mg}$ and $15 \mathrm{mg} / \mathrm{L}$ ) were tested with a contact time of 15 minutes. The USEPA 1623 method was used, and some samples were stained with propidium iodide to distinguish viable and dead cysts. It was found that the $\log _{10}$ reduction was $1.3 \pm 1.8$ and $1.1 \pm 1.9$, respectively, for the two doses evaluated.

Thus, ozonation is effective against Giardia, but a 3 $\log _{10}$ inactivation requires higher ozone exposure compared to bacteria. In turn, this raises concerns about the formation of by-products, such as bromides, a potential carcinogenic compound (Von Gunten, 2003). Another point of concern is the inverse correlation between cyst concentration and disinfection efficacy (Haas and Kaymak, 2003), which is of relevance considering that laboratory studies usually employed large number of cysts, a situation that do not represent the natural concentration of cysts in real world waters.

Alternative disinfection methods are being considered, and organic acids have gained attention because of disinfection-by- products. Per-acids such as peracetic acid (PAA) and performic acid (PFA) are organic peroxides. The suggested disinfection mechanisms of PAA are based on the release of highly reactive oxygen species (ROS) such as hydroxyl, alkoxyl and hydroperoxyl radicals and superoxide. A study evaluated the disinfection efficiency of PFA against various microbial contaminants, including Giardia, on secondary-treated wastewater (Karpova et al 2013). While most microorganisms were already efficiently inactivated with $2 \mathrm{mg}$ PFA /L within $5 \mathrm{~min}$, for Giardia cyst this value was $10 \mathrm{mg}$ PFA /L.

\subsubsection{Physical disinfection (Ultraviolet)}

Ultraviolet disinfection has been introduced at many 
water and wastewater treatment plants as a microorganism reduction method, with the majority employing monochromatic low-pressure (LP) UV lamps for irradiation.

Relatively low doses of UV (1-9 $\mathrm{mJ} / \mathrm{cm}^{2}$ ) have been shown to inactivate $2-4 \log _{10}$ of Giardia cysts in one study (Linden et al., 2002). Similar findings were obtained using the G. duodenalis, WB isolate, and a gerbil model of infection (Campbell and Wallis, 2002): up to $2 \log _{10}$ inactivation was observed at a UV dose of approximately 10 $\mathrm{mJ} / \mathrm{cm}^{2}$ (range 9.3-11.7 mJ/ $\mathrm{cm}^{2}$ ). Higher UV doses (between 20 and $40 \mathrm{~mJ} / \mathrm{cm}^{2}$ ) resulted in up to $3 \log _{10}$ inactivation of the cysts. The most recent study indicates that cysts could not survive irradiation doses higher than 5 $\mathrm{mJ} / \mathrm{cm}^{2}$ (Einarsson et al., 2015). Cysts exposed even to the lowest dose $\left(1 \mathrm{~mJ} / \mathrm{cm}^{2}\right)$ of medium pressure (MP) UV irradiation failed to establish an infection in gerbils (Shin et al., 2010). The capability of Giardia cysts to repair UVmediated DNA damage and maintain infectivity has also been investigated. A recent study showed that UV treatment did not actually kill the cell but damaged its DNA, in agreement with the hypothesis that the replication machinery is important for survival of Giardia(Einarsson et al., 2015). Indeed, mature cysts might not have had an active replication machinery at the time of irradiation, and are therefore unable to detect and repair the DNA lesions. 


\section{References}

Adam, E.A., Yoder, J.S., Gould, L.H., Hlavsa, M.C. and Gargano, J.W. (2016). Giardiasis outbreaks in the United States, 1971-2011. Epidemiology and Infection. 11, pp. 1-12.

Adam, R.D., Dahlstrom, E.W., Martens, C.A., Bruno, D.P., Barbian, K.D., Ricklefs, S.M. et al. (2013). Genome sequencing of Giardia lamblia genotypes A2 and B isolates (DH and GS) and comparative analysis with the genomes of genotypes A1 and E (WB and Pig). Genome Biology and Evolution. 5, pp. 2498-2511.

Adell, A.D., Smith, W.A., Shapiro, K., Melli, A. and Conrad, P.A. (2014). Molecular epidemiology of Cryptosporidium spp. and Giardia spp. in mussels (Mytilus californianus) and California sea lions (Zalophus californianus) from Central California. Applied and Environmental Microbiology. 80, pp. 7732-7740.

Ahmed, W., Hodgers, L., Sidhu, J.P. and Toze, S. (2012). Fecal indicators and zoonotic pathogens in household drinking water taps fed from rainwater tanks in southeast Queensland, Australia. Applied and Environmental Microbiology. 78, pp. 219-226.

Ajonina, C., Buzie, C. and Otterpohl, R. (2013). The detection of Giardia cysts in a large-scale wastewater treatment plant in Hamburg, Germany. Journal of Environmental Science and Health. 76, pp. 509-514.

Almeida, A., Moreira, M.J., Soares, S., L Mde, D., Figueiredo, J., Silva, E. et al. (2010). Presence of Cryptosporidium spp. and Giardia duodenalis in drinking water samples in the north of Portugal. Korean Journal of Parasitology. 48, pp. 43-48.

Alum, A., Absar, I.M., Asaad, H.,,. and Ijaz, M.K. (2014). Impact of environmental conditions on the survival of Cryptosporidium and Giardia on environmental surfaces. Interdisciplinary Perspectives on Infectious Diseases. 2014, pp. 210385.

Amahmid, O., Asmama, S. and Bouhoum, K. (1999). The effect of waste water reuse in irrigation on the contamination level of food crops by Giardia cysts and Ascaris eggs. International Journal of Food Microbiology. 49, pp. 19-26.

Anceno, A.J., Ozaki, M., Dang, Y.N., Chuluun, B. and Shipin, O.V. (2007). Canal networks as extended waste stabilization ponds: fate of pathogens in constructed waterways in Pathumthani Province, Thailand. Water Science and Technology. 55, pp. 143-156.

Azman, J., Init, I., Wan, J. and Yusoff, W.S. (2009). Occurrence of Giardia and Cryptosporidium (oo)cysts in the river water of two recreational areas in Selangor, Malaysia. Tropical Biomedicine. 26, pp. 289-302.

Bajer, A., Toczylowska, B., Bednarska, M. and Sinski, E. (2012). Effectiveness of water treatment for the removal of Cryptosporidium and Giardia spp. Epidemiology and Infection. 140, pp. 2014-2022.

Baldursson, S. and Karanis, P. (2011). Waterborne transmission of protozoan parasites: review of worldwide outbreaks - an update 2004-2010. Water Research. 45, pp. 6603-6614.

Ballweber, L.R., Xiao, L., Bowman, D.D., Kahn, G. and Cama, V.A. (2010). Giardiasis in dogs and cats: update on epidemiology and public health significance. Trends in Parasitology. 26, pp. 180-189. 
Bean, C.L., Hansen, J.J., Margolin, A.B., Balkin, H., Batzer, G. and Wildmer, G. (2007). Class B alkaline stabilization to achieve pathogen inactivation. International Journal of Environmental Research and Public Health. 4, pp. 53-60.

Ben Ayed, L., Yang, W., Widmer, G., Cama, V., Ortega, Y. and Xiao, L. (2012). Survey and genetic characterization of wastewater in Tunisia for Cryptosporidium spp., Giardia duodenalis, Enterocytozoon bieneusi, Cyclospora cayetanensis and Eimeria spp. Journal of Water and Health. 10, pp. 431-444.

Betancourt, W.Q., Duarte, D.C., Vásquez, R.C. and Gurian, P.L. (2014). Cryptosporidium and Giardia in tropical recreational marine waters contaminated with domestic sewage: estimation of bathing-associated disease risks. Marine Pollution Bulletin. 85, pp. 268-273.

Betancourt, W.Q. and Mena, K.D. (2012). Assessment of waterborne protozoan passage through conventional drinking water treatment process in Venezuela. J. Journal of Water and Health. 10, pp. 324-336.

Bingham, A.K., Jarroll, E.L. and Meyer, E.A. (1979). Giardia sp.: physical factors of excystation in vitro, and excystation vs. eosin exclusion as determinants of viability. Experimental Parasitology. 47, pp. 284-291.

T Bonatti, R., Franco, RM.Bueno and R Neto, C. (2007). Comparison of two methodologies for detection of Giardia spp. cysts and Cryptosporidium spp. oocysts in activated sludge samples from a sewage treatment plant in the city of Campinas, São Paulo State, Brazil. Journal of Water and Health. 5, pp. 609-614.

Branco, N., Leal, D.A. and Franco, R.M. (2012). A parasitological survey of natural water springs and inhabitants of a tourist city in southeastern Brazil. Vector-Borne and Zoonotic Diseases. 12, pp. 410-417.

Briancesco, R. and Bonadonna, L. (2005). An Italian study on Cryptosporidium and Giardia in wastewater, fresh water and treated water. Environmental Monitoring and Assessment. 104, pp. 445-447.

Budu-Amoako, E., Greenwood, S.J., Dixon, B.R., Barkema, H.W. and McClure, J.T. (2012). Occurrence of Cryptosporidium and Giardia on beef farms and water sources within the vicinity of the farms on Prince Edward Island, Canada. Vet. Parasitol. 184, pp. 1-9.

Cacciò, S.M., De Giacomo, M., Aulicino, F.A. and Pozio, E. (2003). Giardia cysts in wastewater treatment plants in Italy. Applied and Environmental Microbiology. 69, pp. 3393-3398.

Cacciò, S.M. (2015). Giardiasis: a zoonotic infection or not?. Zoonoses-infections affecting humans and animals. (Sing, A., ed.). Springer Wien. New York. pp. 821-848.

Cacciò, S.M. and Sprong, H. (2014). Epidemiology of giardiasis in humans. Giardia: a model organism. (Lujan, H.D. and Svard, S., ed.). Springer Wien. New York. pp. 16-28.

Campbell, A.T. and Wallis, P. (2002). The effect of UV irradiation on human-derived Giardia lamblia cysts. Water Research. 36, pp. 963-969.

Carmena, D., Aguinagalde, X., Zigorraga, C., Fernández-Crespo, J.C. and Ocio, J.A. (2007). Presence of Giardia cysts and Cryptosporidium oocysts in drinking water supplies in northern Spain. Journal of Applied Microbiology. 102, pp. 619-629. 
Carmena, D. (2010). Waterborne transmission of Cryptosporidium and Giardia: detection, surveillance and implications for public health. Current Research, Technology and Education Topics in Applied Microbiology and Microbial Biotechnology. (Mendez-Vilas, A., ed.). Formatex. Badajoz. pp. 3-14.

Castro-Hermida, J.A., García-Presedo, I., Almeida, A., González-Warleta, M., Da Costa, J.M. and Mezo, M. (2009). Detection of Cryptosporidium spp. and Giardia duodenalis in surface water: a health risk for humans and animals. Water Research. 43, pp. 4133-4142.

Castro-Hermida, J.A., García-Presedo, I., Almeida, A., González-Warleta, M., Da Costa, JM.Correia and Mezo, M. (2008). Presence of Cryptosporidium spp. and Giardia duodenalis through drinking water. Science of the Total Environment. 405, pp. 45-53.

Castro-Hermida, J.A., García-Presedo, I., González-Warleta, M. and Mezo, M. (2010). Cryptosporidium and Giardia detection in water bodies of Galicia, Spain. Water Research. 44, pp. 5887-5896.

Castro-Hermida, J.A., González-Warleta, M. and Mezo, M. (2015). Cryptosporidium spp. and Giardia duodenalis as pathogenic contaminants of water in Galicia, Spain: the need for safe drinking water. International Journal of Hygiene and Environmental Health. 218, pp. 132-138.

Chaidez, C., Soto, M., Gortares, P. and Mena, K. (2005). Occurrence of Cryptosporidium and Giardia in irrigation water and its impact on the fresh produce industry. International Journal of Environmental Research and Public Health. 15, pp. $339-345$.

Cheng, H.W., Lucy, F.E., Graczyk, T.K., Broaders, M.A., Tamang, L. and Connolly, M. (2009). Fate of Cryptosporidium parvum and Cryptosporidium hominis oocysts and Giardia duodenalis cysts during secondary wastewater treatments. Parasitology Research. 105, pp. 689-696.

Coupe, S., Delabre, K., Pouillot, R., Houdart, S., Santillana-Hayat, M. and Derouin, F. (2006). Detection of Cryptosporidium, Giardia and Enterocytozoon bieneusi in surface water, including recreational areas: a one-year prospective study. FEMS Immunology and Medical Microbiology. 47, pp. 351-359.

Dahl, R. (2014). Advanced thinking. Environmental Health Perspectives. 122, pp. A332-335.

de Regnier, D.P., Cole, L., Schupp, D.G. and Erlandsen, S.L. (1989). Viability of Giardia cysts suspended in lake, river, and tap water. Applied and Environmental Microbiology. 55, pp. 1223-1229.

Dumontet, S., Scopa, A., Kerje, S. and Krovacek, K. (2001). The importance of pathogenic organisms in sewage and sewage sludge. Journal of the Air Waste and Management Association. 51, pp. 848-860.

Dungeni, M. and Momba, M. (2010). The abundance of Cryptosporidium and Giardia spp. in treated effluents produced by four-wastewater treatment plants in the Gauteng Province of South Africa. Water SA. 36, pp. 4.

Edge, T.A., Khan, I.U., Bouchard, R., Hill, S., Locas, A., Moore, L. et al. (2013). Occurrence of waterborne pathogens and Escherichia coli at offshore drinking water intakes in lake Ontario. Applied and Environmental Microbiology. 19, pp. 5799-5813. 
Edzwald, J.K. (2010). Dissolved air flotation and me. Water Research. 44, pp. 2077-2106.

Egorov, A., Paulauskis, J., Petrova, L., Tereschenko, A., Drizhd, N. and Ford, T. (2002). Contamination of water supplies with Cryptosporidium parvum and Giardia lamblia and diarrheal illness in selected Russian cities. International Journal of Hygiene and Environmental Health. 205, pp. 281-289.

Ehsan, A., Geurden, T., Casaert, S., Paulussen, J., De Coster, L., Schoemaker, T. et al. (2015). Occurrence and potential health risk of Cryptosporidium and Giardia in different water catchments in Belgium. Environmental Monitoring and Assessment. 187, pp. 6.

Ehsan, M.A., Casaert, S., Levecke, B., Van Rooy, L., Pelicaen, J., Smis, A. et al. (2015). Cryptosporidium and Giardia in recreational water in Belgium. Journal of Water and Health. 13, pp. 870-878.

Einarsson, E., Svärd, S.G. and Troell, K. (2015). UV irradiation responses in Giardia intestinalis. Experimental Parasitology. 154, pp. 25-32.

Enserink, R., Mughini-Gras, L., Duizer, E., Kortbeek, T. and Van Pelt, W. (2015). Risk factors for gastroenteritis in child day care. Epidemiology and Infection. 143, pp. 2707-2720.

Ensink, J.H., van der Hoek, W. and Amerasinghe, F.P. (2006). Giardia duodenalis infection and wastewater irrigation in Pakistan. Transactions of the Royal Society of Tropical Medicine and Hygiene. 100, pp. 538-542.

Erlandsen, S.L. and Bemrick, W.J. (1987). SEM evidence for a new species, Giardia psittaci. Journal of Parasitology. 73, pp. 623-629.

Erlandsen, S.L., Bemrick, W.J., Wells, C.L., Feely, D.E., Knudson, L.,, et al. (1990). Axenic culture and characterization of Giardia ardeae from the great blue heron (Ardea herodias). Journal of Parasitology. 76, pp. 717-724.

Escobedo, A.A., Almirall, P., Robertson, L.J., Franco, R.M., Hanevik, K., Mørch, K. et al. (2010). Giardiasis: the ever-present threat of a neglected disease. Infectious Disorders - Drug Targets. 10, pp. 329-348.

Feely, D.E. (1988). Morphology of the cyst of Giardia microti by light and electron microscopy. Journal of Protozoology. 35, pp. 52-54.

Feng, Y. and Xiao, L. (2011). Zoonotic potential and molecular epidemiology of Giardia species and giardiasis. Clinical Microbiology Reviews. 24, pp. 110-140.

Feng, Y., Zhao, X., Chen, J., Jin, W., Zhou, X., Li, N. et al. (2011). Occurrence, source, and human infection potential of Cryptosporidium and Giardia spp. in source and tap water in Shanghai, China. Applied and Environmental Microbiology. 77, pp. 3609-3616.

Fewtrell, L., Kaufmann, R.B., Kay, D., Enanoria, W., Haller, L. and Jr, JM.Colford (2005). Water, sanitation, and hygiene interventions to reduce diarrhoea in less developed countries: a systematic review and meta-analysis. The Lancet Infectious Diseases. 5, pp. 42-52. 
Fu, C.Y., Xie, X., Huang, J.J., Zhang, T., Wu, Q.Y., Chen, J.N. et al. (2010). Monitoring and evaluation of removal of pathogens at municipal wastewater treatment plants. Water science and technology : a journal of the International Association on Water Pollution Research. 61, pp. 1589-99. doi: 10.2166/wst.2010.757.

Fu, C.Y., Xie, X., Huang, J.J., Zhang, T., Wu, Q.Y., Chen, J.N. et al. (2010). Monitoring and evaluation of removal of pathogens at municipal wastewater treatment plants. Water Science and Technology. 61, pp. 1589-1599.

Gómez-Couso, H., Méndez-Hermida, F., Castro-Hermida, J.A. and Ares-Mazás, E. (2005). Occurrence of Giardia cysts in mussels (Mytilus galloprovincialis) destined for human consumption. Journal of Food Protection. 68, pp. 1702-1705.

Gómez-Couso, H., Méndez-Hermida, F., Castro-Hermida, J.A. and Ares-Mazás, E. (2005). Giardia in shellfish-farming areas: detection in mussels, river water and waste waters. Veterinary Parasitology. 133, pp. 13-18.

Gallas-Lindemann, C., Sotiriadou, I., Plutzer, J. and Karanis, P. (2013). Prevalence and distribution of Cryptosporidium and Giardia in wastewater and the surface, drinking and ground waters in the Lower Rhine, Germany. Epidemiology and Infection. 141, pp. 9-21.

Geurden, T., Vercruysse, J. and Claerebout, E. (2010). Is Giardia a significant pathogen in production animals?. Experimental Parasitology. 124, pp. 98-106.

Ghoneim, N.H., Abdel-Moein, K.A. and Saeed, H. (2012). Fish as a possible reservoir for zoonotic Giardia duodenalis Assemblages. Parasitology Research. 10, pp. 2193-2196.

Giacometti, A., Cirioni, O., Balducci, M., Drenaggi, D., Quarta, M., De Federicis, M. et al. (1997). Epidemiologic features of intestinal parasitic infections in Italian mental institutions. European Journal of Epidemiology. 13, pp. 825-830.

Giangaspero, A., Papini, R., Marangi, M., Koehler, A.V. and Gasser, R.B. (2014). Cryptosporidium parvum genotype IIa and Giardia duodenalis Assemblage A in Mytilus galloprovincialis on sale at local food markets. International Journal of Food Microbiology. 171, pp. 62-67.

Gilman, R.H., Marquis, G.S., Miranda, E., Vestegui, M. and Martinez, H. (1988). Rapid reinfection by Giardia lamblia after treatment in a hyperendemic Third World community. Lancet. 1, pp. 343-345.

Graczyk, T.K., Kacprzak, M., Neczaj, E., Tamang, L., Graczyk, H., Lucy, F.E. et al. (2008). Occurrence of Cryptosporidium and Giardia in sewage sludge and solid waste landfill leachate and quantitative comparative analysis of sanitization treatments on pathogen inactivation. Environ Research. 106, pp. 27-33.

Graczyk, T.K., Lucy, F.E., Tamang, L., Mashinski, Y., Broaders, M.A., Connolly, M. et al. (2009). Propagation of human enteropathogens in constructed horizontal wetlands used for tertiary wastewater treatment. Applied and Environmental Microbiology. 75, pp. 4531-4538.

Graczyk, T.K., Lucy, F.E., Tamang, L. and Miraflor, A. (2007). Human enteropathogen load in activated sewage sludge and corresponding sewage sludge end products. Applied and Environmental Microbiology. 73, pp. 2013-2015.

Graczyk, T.K., Sunderland, D., Tamang, L., Lucy, F.E. and Breysse, P.N. (2007). Bather density and levels of Cryptosporidium, Giardia, and pathogenic microsporidian spores in recreational bathing water. Parasitology

Research.101, pp. 1729-1731. 
Grit, G.H., Bénéré, E., Ehsan, A., De Wilde, N., Claerebout, E., Vercruysse, J. et al. (2012). Giardia duodenalis cyst survival in cattle slurry. Veterinary Parasitology. 184, pp. 330-334.

Guzman-Herrador, B., Carlander, A., Ethelberg, S., B de Blasio, F., Kuusi, M., Lund, V. et al. (2015). Waterborne outbreaks in the Nordic countries, 1998 to 2012. Eurosurveillance.

Haas, C.N. and Kaymak, B. (2003). Effect of initial microbial density on inactivation of Giardia muris by ozone. Water Research. 37, pp. 2980-2988.

Hachich, E.M., Galvani, A.T., Padula, J.A., Stoppe, N.C., Garcia, S.C., Bonanno, V.M.S. et al. (2013). Pathogenic parasites and enteroviruses in wastewater: support for a regulation on water reuse. Water Science and Technology. 67, pp. 1512-1518.

Haramoto, E., Kitajima, M., Kishida, N., Katayama, H., Asami, M. and Akiba, M. (2012). Occurrence of viruses and protozoa in drinking water sources of Japan and their relationship to indicator microorganisms. Food and Environmental Virology. 4, pp. 93-101.

Haramoto, E., Yamada, K. and Nishida, K. (2011). Prevalence of protozoa, viruses, coliphages and indicator bacteria in groundwater and river water in the Kathmandu Valley, Nepal. Transactions of the Royal Society of Tropical Medicine and Hygiene. 105, pp. 711-716.

Harwood, V.J., Levine, A.D., Scott, T.M., Chivukula, V., Lukasik, J.,., et al. (2005). Validity of the indicator organism paradigm for pathogen reduction in reclaimed water and public health protection. Applied and Environmental Microbiology. 71, pp. 3163-3170.

Hashimoto, A., Hirata, T. and Kunikane, S. (2001). Occurrence of Cryptosporidium oocysts and Giardia cysts in a conventional water purification plant. Water Science and Technology. 43, pp. 89-92.

Hatam-Nahavandi, K., Mahvi, A.H., Mohebali, M., Keshavarz, H., Mobed, I. and Rezaeian, M. (2015). Detection of parasitic particles in domestic and urban wastewaters and assessment of removal efficiency of treatment plants in Tehran, Iran. Journal of Environmental Health Science and Engineering.

Health, C. (2012). Guidelines for Canadian Drinking Water Quality: Guideline Technical Document - Enteric Protozoa: Giardia and Cryptosporidium. Water, Air and Climate Change Bureau, Healthy Environments and Consumer Safety Branch, Health Canada. Ottawa, Ontario.

Hilles, A.H., Hindi, AI.Al and Safieh, YA.Abu (2014). Assessment of parasitic pollution in the coastal seawater of Gaza city. Journal of Environmental Health Science and Engineering. 12, pp. 26.

Hirani, Z.M., Bukhari, Z., Oppenheimer, J., Jjemba, P., LeChevallier, M.W. and Jacangelo, J.G. (2013). Characterization of effluent water qualities from satellite membrane bioreactor facilities. Water Research. 47, pp. 5065-5075.

Hsu, B.M., Huang, C. and Hsu, C.L. (2001). Analysis for Giardia cysts and Cryptosporidium oocysts in water samples from small water systems in Taiwan. Parasitology Research. 87, pp. 163-168. 
Júlio, C., Sá, C., Ferreira, I., Martins, S., Oleastro, M., Angelo, H. et al. (2012). Waterborne transmission of Giardia and Cryptosporidium at river beaches in Southern Europe (Portugal). Journal of Water and Health. 10, pp. 484-496.

Jacob, P., Henry, A., Meheut, G., Charni-Ben-Tabassi, N., Ingrand, V. and Helmi, K. (2015). Health risk assessment related to waterborne pathogens from the river to the tap. International Journal of Hygiene and Environmental Health. 12, pp. 2967-2983.

Jakubowski, W., Sykora, J.L., Sorber, C.A., Casson, L.W. and Gavaghan, P.D. (1991). Determining Giardiasis prevalence by examination of sewage. Water Science and Technology. 24, pp. 173-178.

Johnson, D.C., Enriquez, C.E., Pepper, I.L., Davis, T.L., Gerba, C.P. and Rose, J.B. (1997). Survival of Giardia, Cryptosporidium, poliovirus, and Salmonella in marine waters. Water Science and Technology. 35, pp. $261-268$.

Karanis, P., Kourenti, C. and Smith, H. (2007). Waterborne transmission of protozoan parasites: a worldwide review of outbreaks and lessons learnt. Journal of Water and Health. 5, pp. 1-38.

Karanis, P., Sotiriadou, I., Kartashev, V., Kourenti, C., Tsvetkova, N. and Stojanova, K. (2006). Occurrence of Giardia and Cryptosporidium in water supplies of Russia and Bulgaria. Environmental Research. 102, pp. 260-271.

Karpova, T., Pekonen, P., Gramstad, R., Öjstedt, U., Laborda, S., Heinonen-Tanski, H. et al. (2013). Performic acid for advanced wastewater disinfection. Water Science and Technology. 68, pp. 2090-2096.

Khouja, L.B.A., Cama, V. and Xiao, L. (2010). Parasitic contamination in wastewater and sludge samples in Tunisia using three different detection techniques. Parasitology Research. 107, pp. 109-116.

Kistemann, T., Rind, E., Koch, C., Clasen, T., Lengen, C., Exner, M. et al. (2012). Effect of sewage treatment plants and diffuse pollution on the occurrence of protozoal parasites in the course of a small river. International Journal of Hygiene and Environmental Health. 215, pp. 577-583.

Kistemann, T., Rind, E., Rechenburg, A., Koch, C., Classen, T., Herbst, S. et al. (2008). A comparison of efficiencies of microbiological pollution removal in six sewage treatment plants with different treatment systems. International Journal of Hygiene and Environmental Health. 211, pp. 534-545.

Kitajima, M., Haramoto, E., Iker, B.C. and Gerba, C.P. (2014). Occurrence of Cryptosporidium, Giardia, and Cyclospora in influent and effluent water at wastewater treatment plants in Arizona. Science of the Total Environment. 484, pp. 129-136.

Lahnsteiner, J. and Lempert, G. (2007). Water management in Windhoek, Namibia. Water Science and Technology. 55, pp. 441-448.

Lalancette, C., Généreux, M., Mailly, J., Servais, P., Côté, C., Michaud, A. et al. (2012). Total and infectious Cryptosporidium oocyst and total Giardia cyst concentrations from distinct agricultural and urban contamination sources in Eastern Canada. Journal of Water and Health. 10, pp. 147-160.

Lalle, M. (2010). Giardiasis in the post genomic era: treatment, drug resistance and novel therapeutic perspectives. Infectious Disorders - Drug Targets. 10, pp. 283-294. 
Lim, Y.A., Ahmad, R.A. and Smith, H.V. (2008). Current status and future trends in Cryptosporidium and Giardia epidemiology in Malaysia. Journal of Water and Health. 6, pp. 239-254.

Lim, Y.A., Ramasame, S.D., Mahdy, M.A., Sulaiman, W.Y. and Smith, H.V. (2009). Detection and molecular characterization of Giardia isolated from recreational lake water in Malaysia. Parasitology Research. 106, pp. 289-291.

Lim, Y.A.L., Wan Hafiz, W.I. and Nissapatorn, V. (2007). Reduction of Cryptosporidium and Giardia by sewage treatment processes. Tropical Biomedicine. 24, pp. 95-104.

Linden, K.G., Shin, G.A., Faubert, G., Cairns, W. and Sobsey, M.D. (2002). UV disinfection of Giardia lamblia cysts in water. Environmental Science and Technology. 36, pp. 2519-2522.

Lobo, M., Xiao, L., Antunes, F. and Matos, O. (2009). Occurrence of Cryptosporidium and Giardia genotypes and subtypes in raw and treated water in Portugal. Letters in Applied Microbiology. 48, pp. 732-737.

Lonigro, A., Pollice, A., Spinelli, R., Berrilli, F., Di Cave, D., D'Orazi, C. et al. (2006). Giardia cysts and Cryptosporidium oocysts in membrane-filtered municipal wastewater used for irrigation. Applied and Environmental Microbiology. 72, pp. 7916-7918.

Lucy, F.E., Graczyk, T.K., Tamang, L., Miraflor, A. and Minchin, D. (2008). Biomonitoring of surface and coastal water for Cryptosporidium, Giardia, and human-virulent microsporidia using molluscan shellfish. Parasitology Research. 103, pp. 1369-1375.

Magana-Ordorica, D., Mena, K., Valdez-Torres, J.B., Soto-Beltran, M., Leon-Felix, J. and Chaidez, C. (2010). Relationships between the occurrence of Giardia and Cryptosporidium and physicochemical properties of marine waters of the Pacific Coast of Mexico. Journal of Water and Health. 8, pp. 797-802.

Mahmoudi, M.R., Kazemi, B., Mohammadiha, A., Mirzaei, A. and Karanis, P. (2013). Detection of Cryptosporidium and Giardia (oo)cysts by IFA, PCR and LAMP in surface water from Rasht, Iran. Transactions of the Royal Society of Tropical Medicine and Hygiene. 107, pp. 511-517.

Ma, J., Feng, Y., Hu, Y., Villegas, E.N. and Xiao, L. (2016). Human infective potential of Cryptosporidium spp., Giardia duodenalis and Enterocytozoon bieneusi in urban wastewater treatment plant effluents. Journal of Water and Health. 14, pp. 411-423.

McBride, G.B., Stott, R., Miller, W., Bambic, D. and Wuertz, S. (2013). Discharge-based QMRA for estimation of public health risks from exposure to stormwater-borne pathogens in recreational waters in the United States. Water research. 47, pp. 5282-5297. doi: 10.1016/j.watres.2013.06.001.

Ministers, N.Council of (2007). Protozoan Parasites in Sewage Sludge. TemaNord, Nordic Council of Ministers. Copenhagen. doi: http://dx.doi.org/10.6027/tn2006-596.

Monis, P.T., Andrews, R.H., Mayrhofer, G. and Ey, P.L. (1999). Molecular systematics of the parasitic protozoan Giardia intestinalis. Molecular Biology and Evolution. 16, pp. 1135-1144. 
Monis, P.T., Cacciò, S.M. and Thompson, R.C.A. (2009). Variation in Giardia: towards a taxonomic revision of the genus. Trends in Parasitology. 25, pp. 93-100.

Mons, C., Dumètre, A., Gosselin, S., Galliot, C. and Moulin, L. (2009). Monitoring of Cryptosporidium and Giardia river contamination in Paris area. Water Research. 43, pp. 211-217.

Mtapuri-Zinyowera, S., Midzi, N., Muchaneta-Kubara, C.E., Simbini, T. and Mduluza, T. (2009). Impact of solar radiation in disinfecting drinking water contaminated with Giardia duodenalis and Entamoeba histolytica/dispar at a point-of-use water treatment. Journal of Applied Microbiology. 106, pp. 847-852.

Neto, R.C., Santos, L.U. and Franco, R.M. (2006). Evaluation of activated sludge treatment and the efficiency of the disinfection of Giardia species cysts and Cryptosporidium oocysts by UV at a sludge treatment plant in Campinas, southeast Brazil. Water Science and Technology. 54, pp. 89-94.

Nishi, L., Baesso, M.L., Santana, R.G., Fregadolli, P., Falavigna, D.L. and Falavigna-Guilherme, A.L. (2009). Investigation of Cryptosporidium spp. and Giardia spp. in a public water-treatment system. Zoonoses and Public Health. 56, pp. 221-228.

Nygaard, K., Schimmer, B., Sobstad, O., Walde, A., Tveit, I., Langeland, N. et al. (2006). A large community outbreak of waterborne giardiasis-delayed detection in a non-endemic urban area. BMC Public Health. 6, pp. 141.

Oda, T., Kawabata, M. and Uga, S. (2005). Detection of Giardia cysts in sewage and estimations of giardiasis prevalence among inhabitants in Hyogo Prefecture, Japan. Trop. Med. Health. 33, pp. 1-5.

Oliveri, R., Di Piazza, F., Marsala, B., Cerame, G., Firenze, A. and Di Benedetto, M.A. (2006). Occurrence of Giardia cysts and Cryptosporidium oocysts in swimming pools in the province of Palermo, Italy. Annali di igiene. 18, pp. 367-374.

Olson, M.E., Goh, J., Phillips, M., Guselle, N. and McAllister, T.A. (1999). Giardia cyst and Cryptosporidium oocyst survival in water, soil and, cattle feces. Journal of Environmental Quality. 28, pp. 1991-1996.

Onichandran, S., Kumar, T., Salibay, C.C., Dungca, J.Z., Tabo, H.A., Tabo, N. et al. (2014). Waterborne parasites: a current status from the Philippines. Parasit. Vectors. 7, pp. 244.

Pachepsky, Y., Shelton, D.R., McLain, J.E.T., Patel, J. and Mandrell, R.E. (2011). Irrigation Waters as a Source of Pathogenic Microorganisms in Produce: A Review. Burlington: Academic Press.

Painter, J.E., Gargano, J.W., Collier, S.A. and Yoder, J.S. (2015). Centers for Disease Control and Prevention. Giardiasis surveillance - United States, 2011-2012. MMWR Supplements. 64, pp. 15-25.

Percival, S., Chalmers, R., Embrey, M., Hunter, P., Sellwood, J. and Wyn-Jones, P. (2004). Microbiology of Waterborne Diseases. Elsevier Academic Press. 1st editio ed. Elsevier Academic Press. California.

Plutzer, J., Karanis, P., Domokos, K., Törökné, A. and K, M. (2008). Detection and characterization of Giardia and Cryptosporidium in Hungarian raw, surface and sewage water samples by IFT, PCR and sequence analysis of the SSUrRNA and GDH genes. International Journal of Hygiene and Environmental Health. 211, pp. 524-533. 
Plutzer, J., Takó, M.H., Márialigeti, K., Törökné, A. and Karanis, P. (2007). First investigations into the prevalence of Cryptosporidium and Giardia spp. in Hungarian drinking water. Journal of Water and Health. 5, pp. 573-84.

Prystajecky, N., Huck, P.M., Schreier, H. and Isaac-Renton, J.L. (2014). Assessment of Giardia and Cryptosporidium spp. as a microbial source tracking tool for surface water: application in a mixed-use watershed. Applied and Environmental Microbiology. 80, pp. 2328-2336.

Qadir, M., Wichelns, D., Raschid-Sally, L., McCornick, P.G., Drechsel, P., Bahri, A. et al. (2010). The challenges of wastewater irrigation in developing countries. Agricultural Water Management. 97, pp. 561-568.

Ramírez-Castillo, F.Y., Loera-Muro, A., Jacques, M., Garneau, P., Avelar-González, F.J., Harel, J. et al. (2015). Waterborne pathogens: detection methods and challenges. Pathogens. 4, pp. 307-334.

Razzolini, M.T., Santos, TF.da Silva and Bastos, V.K. (2010). Detection of Giardia and Cryptosporidium cysts/oocysts in watersheds and drinking water sources in Brazil urban areas. Journal of Water and Health. 8, pp. 399-404.

der, A., Dürr, M., Daeschlein, G., Baeder-Bederski, O., Koch, C., Müller, R. et al. (2010). Constructed wetlands-Are they safe in reducing protozoan parasites?. International Journal of Hygiene and Environmental Health. 2013, pp. 72-77.

Reinoso, R., Blanco, S., Torres-Villamizar, L.A. and Becares, E. (2011). Mechanisms for parasites removal in a waste stabilisation pond. Microbial Ecology. 61, pp. 684-692.

Reinoso, R., Torres, L.A. and Becares, E. (2008). Efficiency of natural systems for removal of bacteria and pathogenic parasites from wastewater. Science of the Total Environment. 395, pp. 80-86.

dtorff, R.C. (1954). he experimental transmission of human intestinal protozoan parasites. II. Giardia lamblia cysts given in capsules. American Journal of Hygiene. 59, pp. 209-220.

Rhodes, E.R., Boczek, L.A., Ware, M.W., McKay, M., Hoelle, J.M., Schoen, M. et al. (2015). Determining pathogen and indicator levels in class B municipal organic residuals used for land application. Journal of environmental quality. 44(1), pp. 265-274.

Rhodes, E.R., Villegas, L.F., Shaw, N.J., Miller, C. and Villegas, E.N. (2012). A modified EPA Method 1623 that uses tangential flow hollow-fiber ultrafiltration and heat dissociation steps to detect waterborne Cryptosporidium and Giardia spp. Journal of Visualized Experiments. 65, pp. 4177.

Rijal, G., Tolson, J.K., Petropoulou, C., Granato, T.C., Glymph, A., Gerba, C. et al. (2011). Microbial risk assessment

Rimhanen-Finne, R., Ronkainen, P. and Hänninen, M.L. (2001). Simultaneous detection of Cryptosporidium parvum and Giardia in sewage sludge by IC-PCR. Journal of Applied Microbiology. 91, pp. 1030-1035.

Rimhanen-Finne, R., Vuorinen, A., Marmo, S., Malmberg, S. and Hänninen, M.L. (2004). Comparative analysis of Cryptosporidium, Giardia and indicator bacteria during sewage sludge hygienization in various composting processes.

Letters in Applied Microbiology. 38, pp. 301-305. 
Robertson, L.J. and Gjerde, B. (2001). Occurrence of Cryptosporidium oocysts and Giardia cysts in raw waters in Norway. Scandinavian Journal of Public Health. 29, pp. 200-207.

Robertson, L.J., Hermansen, L. and Gjerde, B. (2006). Occurrence of Cryptosporidium oocysts and Giardia Cysts in sewage in Norway. Applied and Environmental Microbiology. 72, pp. 5297-5303.

Robertson, L.J. and Lim, Y.A.L. (2014). Waterborne and environmentally-borne giardiasis. Giardia: a model organism. (Lujan, H.D. and Svard, S., ed.). Springer Wien. New York. pp. 29-69.

Rodriguez-Manzano, J., Alonso, J.L., Ferrús, M.A., Moreno, Y., Amorós, I., Calque, B. et al. (2012). Standard and new faecal indicators and pathogens in sewage treatment plants, microbiological parameters for improving the control of reclaimed water. Water Science and Technology. 66, pp. 2517-23.

Rose, J.B., Huffman, D.E., Riley, K.,.., Lukasik, J.O. and Hamann, C.L. (2001). Reduction of enteric microorganisms at the Upper Occoquan Sewage Authority Water Reclamation Plant. Water Environment Research. 73, pp. 711-720.

Ryan, U. and Cacciò, S.M. (2013). Zoonotic potential of Giardia. International Journal for Parasitology. 43, pp. 943-956.

Ryu, H. and Abbaszadegan, M. (2008). Long-term study of Cryptosporidium and Giardia occurrence and quantitative microbial risk assessment in surface waters of Arizona in the USA. Journal of Water and Health. 6, pp. 263-273.

Samie, A. and Ntekele, P. (2014). Genotypic detection and evaluation of the removal efficiency of Giardia duodenalis at municipal wastewater treatment plants in Northern South Africa. Tropical Biomedicine. 31, pp. 122-133.

Santos, L.U., Bonatti, T.R., R Neto, C. and Franco, R.M.B. (2004). Occurrence of Giardia cysts and Cryptosporidium oocysts in activated sludge samples in Campinas, SP, Brazil. Revista do Instituto de Medicina Tropical de São Paulo. 46, pp. 309-313.

Sato, M.I., Galvani, A.T., Padula, J.A., Nardocci, A.C., S Mde, L., Razzolini, M.T. et al. (2013). Assessing the infection risk of Giardia and Cryptosporidium in public drinking water delivered by surface water systems in Sao Paulo State, Brazil. Science of the Total Environment. 442, pp. 389-396.

Savioli, L., Smith, H. and Thompson, R.C.A. (2006). Giardia and Cryptosporidium join the 'Neglected Diseases Initiative'. Trends in Parasitology. 22, pp. 203-207.

Schets, F.M., van den Berg, H.H., Engels, G.B., Lodder, W.J. and De Roda Husman, A.M. (2007). Cryptosporidium and Giardia in commercial and non-commercial oysters (Crassostrea gigas) and water from the Oosterschelde, The Netherlands. International Journal of Food Microbiology. 113, pp. 189-194.

Schets, F.M., van Wijnen, J.H., Schijven, J.F., Schoon, H. and De Roda Husman, A.M. (2008). Monitoring of waterborne pathogens in surface waters in Amsterdam, the Netherlands, and the potential health risk associated with exposure to Cryptosporidium and Giardia in these waters. Appl. Environ. Microbiol. 74, pp. 2069-2078. 
Sheludchenko, M., Padovan, A., Katouli, M. and Stratton, H. (2016). Removal of fecal indicators, pathogenic bacteria, Adenovirus, Cryptosporidium and Giardia (oo)cysts in waste stabilization ponds in Northern and Eastern Australia. International Journal of Environmental Research and Public Health. 13,.

Shield, J.M., Gleim, E.R. and Beach, M.J. (2008). Prevalence of Cryptosporidium spp. and Giardia intestinalis in swimming pools, Atlanta, Georgia. Emerging Infectious Diseases. 14, pp. 948-950.

Shin, G., Linden, K.G. and Faubert, G. (2010). Reactivation of Giardia lamblia cysts after exposure to polychromatic UV light. Letters in Applied Microbiology. 51, pp. 395-399.

Skotarczak, B. (2009). Methods for parasitic protozoan's detection in environmental samples. Parasite. 16, pp. 183-190.

Souza, D.S., Ramos, A.P., Nunes, F.F., Moresco, V., Taniguchi, S., Leal, D.A. et al. (2012). Evaluation of tropical water sources and mollusks in southern Brazil using microbiological, biochemical, and chemical parameters. Ecotoxicology and Environmental Safety. 76, pp. 153-161.

Spanakos, G., Biba, A., Mavridou, A. and Karanis, P. (2015). Occurrence of Cryptosporidium and Giardia in recycled waters used for irrigation and first description of Cryptosporidium parvum and C. muris in Greece. Parasitology Research. 114, pp. 1803-1810.

Speich, B., Croll, D., Fürst, T., Utzinger, J. and Keiser, J. (2016). Effect of sanitation and water treatment on intestinal protozoa infection: a systematic review and meta-analysis. The Lancet Infectious Diseases. 16, pp. 87-99.

Sroka, J., Stojecki, K., Zdybel, J., Karamon, J., Cencek, T. and Dutkiewicz, J. (2013). Occurrence of Cryptosporidium oocysts and Giardia cysts in effluent from sewage treatment plant from eastern Poland. Annals of Agricultural and Environmental Medicine. 1, pp. 57-62.

Stark, D., Barratt, J.L., van Hal, S., Marriott, D., Harkness, J. and Ellis, J.T. (2009). Clinical significance of enteric protozoa in the immunosuppressed human population. Clinical Microbiology Reviews.

Strunz, E.C., Addiss, D.G., Stocks, M.E., Ogden, S., Utzinger, J. and Freeman, M.C. (2014). Water, sanitation, hygiene, and soil-transmitted helminth infection: a systematic review and meta-analysis. PLoS Medicine. 11, pp. e1001620.

Sulaiman, I.M., Jiang, J., Singh, A. and Xiao, L. (2004). Distribution of Giardia duodenalis genotypes and subgenotypes in raw urban wastewater in Milwaukee, Wisconsin. Applied and Environmental Microbiology. 70, pp. 3776-3780.

Thompson, R.C.A. and Monis, P.T. (2012). Giardia- from genome to proteome. Advances in Parasitology. 78, pp. 57-95.

Thurston-Enriquez, J.A., Watt, P., Dowd, S.E., Enriquez, R., Pepper, I.L. and Gerba, C.P. (2002). Detection of protozoan parasites and microsporidia in irrigation waters used for crop production. Journal of Food Protection. 65, pp. 378-382.

Tondera, K., Klaer, K., Koch, C., Hamza, I.A. and Pinnekamp, J. (2016). Reducing pathogens in combined sewer overflows using performic acid. International Journal of Hygiene and Environmental Health. S1438-4639, pp. 30032-30033.

USEPA (2012). Method 1623.1: Cryptosporidium and Giardia in water by filtration/IMS/FA.1 EPA 816-R-12-001. 
USEPA (2005). Final Long Term 2 Enhanced Surface Water Treatment Rule. Office of Water (4606-M) EPA 815-R-06-002 December 2005 www.epa.gov/safewater.

Usman, K., Khan, S., Ghulam, S., Khan, M.U., Khan, N., Khan, M.A. et al. (2012). Sewage sludge: An important biological resource for sustainable agriculture and its environmental implications. American Journal of Plant Sciences. 2, pp. 1708-1721.

Vernile, A., Nabi, A.Q., Bonadonna, L., Briancesco, R. and Massa, S. (2009). Occurrence of Giardia and Cryptosporidium in Italian water supplies. Environmental Monitoring and Assessment. 152, pp. 203-207.

von Gunten, U. (2003). Ozonation of drinking water: part II. Disinfection and by-product formation in presence of bromide, iodide or chlorine. Water Research. 37, pp. 1469-1487.

Wallender, E.K., Ailes, E.C., Yoder, J.S., Roberts, V.A. and Brunkard, J.M. (2014). Contributing factors to disease outbreaks associated with untreated groundwater. Groundwater. 52, pp. 886-897.

Wen, Q., Tutuka, C., Keegan, A. and Jin, B. (2009). Fate of pathogenic microorganisms and indicators in secondary activated sludge wastewater treatment plants. Journal of Environmental Management. 90, pp. 1442-1447.

Wen, Q., Tutuka, C., Keegan, A. and Jin, B. (2009). Fate of pathogenic microorganisms and indicators in secondary activated sludge wastewater treatment plants. Journal of Environmental Management. 90, Elsevier Ltd. pp. $1442-1447$. doi: 10.1016/j.jenvman.2008.09.002.

WHO (2006). Guidelines for the safe use of wastewater, excreta and greywater, Volume 3: Wastewater and excreta use in aquaculture. World Health Organization. Geneva.

WHO (1996). The World Health Report, 1996. World Health Organization. Geneva.

Wicki, M., Svoboda, P. and Tanner, M. (2009). Occurrence of Giardia lamblia in recreational streams in Basel-Landschaft, Switzerland. Environmental Research. 109, pp. 524-527.

Willis, J.E., McClure, J.T., Davidson, J., McClure, C. and Greenwood, S.J. (2013). Global occurrence of Cryptosporidium and Giardia in shellfish: Should Canada take a closer look?. Food Research International. 52, pp. 119-135.

Xiao, G., Qiu, Z., Qi, J., Chen, J.A., Liu, F., Liu, W. et al. (2013). Occurrence and potential health risk of Cryptosporidium and Giardia in the Three Gorges Reservoir, China. Water Research. 47, pp. 2431-2445.

Yang, R., Reid, A., Lymbery, A. and Ryan, U. (2010). Identification of zoonotic Giardia genotypes in fish. International Journal for Parasitology. 40, pp. 779-785.

Yapo, R.I., Koné, B., Bonfoh, B., Cissé, G., Zinsstag, J. and Nguyen-Viet, ì.H. (2014). Quantitative microbial risk assessment related to urban wastewater and lagoon water reuse in Abidjan, Côte d'Ivoire. Journal of Water and

Health. 12, pp. 301-309. 
Yason, J.A. and Rivera, W.L. (2007). Genotyping of Giardia duodenalis isolates among residents of slum area in Manila, Philippines. Parasitology Research. 101, pp. 681-687.

Zhang, K., G, A., Sadiq, R., Langford, C.H. and Dore, M.H. (2012). An integrated performance assessment framework for water treatment plants. Water Research. 46, pp. 1673-1683.

Zhang, Y., Chen, Z., Na, W., Xiao, S., Yuan, H., Zhang, D. et al. (2015). Risk assessment of Giardia from a full scale MBR sewage treatment plant caused by membrane integrity failure. Journal of Environmental Science and

Health. 30, pp. 252-258. 